\title{
Economic Analysis of the Investments in Battery Energy Storage Systems: Review and Current Perspectives
}

\author{
Paulo Rotella Junior ${ }^{1,2, *(\mathbb{D})}$, Luiz Célio Souza Rocha ${ }^{3} \mathbb{D}$, Sandra Naomi Morioka ${ }^{1}$, Ivan Bolis ${ }^{4}$, \\ Gianfranco Chicco ${ }^{5}$, Andrea Mazza ${ }^{5}$ (D) and Karel Janda ${ }^{2,6}$ \\ 1 Department of Production Engineering, Federal University of Paraiba, João Pessoa 58051-900, Brazil; \\ sandra.morioka@academico.ufpb.br \\ 2 Faculty of Finance and Accounting, Prague University of Economics and Business, \\ 13067 Prague, Czech Republic; karel-janda@seznam.cz \\ 3 Department of Management, Federal Institute of Education, Science and Technology-North of Minas Gerais, \\ Almenara 39900-000, Brazil; luizrochamg@hotmail.com \\ 4 Department of Psychology, Federal University of Paraiba, João Pessoa 58051-900, Brazil; \\ bolis.ivan@alumni.usp.br \\ 5 Dipartimento Energia "Galileo Ferraris", Politecnico di Torino, 10129 Torino, Italy; \\ gianfranco.chicco@polito.it (G.C.); andrea.mazza@polito.it (A.M.) \\ 6 Institute of Economic Studies, Faculty of Social Sciences, Charles University, 11000 Prague, Czech Republic \\ * Correspondence: paulo.rotella@academico.ufpb.br
}

Citation: Rotella Junior, P.; Rocha, L.C.S.; Morioka, S.N.; Bolis, I.; Chicco, G.; Mazza, A.; Janda, K. Economic Analysis of the Investments in Battery Energy Storage Systems: Review and Current Perspectives. Energies 2021, 14, 2503. https://doi.org/10.3390/ en14092503

Academic Editor: Seon-Ju Ahn

Received: 21 March 2021

Accepted: 26 April 2021

Published: 27 April 2021

Publisher's Note: MDPI stays neutral with regard to jurisdictional claims in published maps and institutional affiliations.

Copyright: (C) 2021 by the authors. Licensee MDPI, Basel, Switzerland. This article is an open access article distributed under the terms and conditions of the Creative Commons Attribution (CC BY) license (https:// creativecommons.org/licenses/by/ $4.0 /)$.

\begin{abstract}
Sources such as solar and wind energy are intermittent, and this is seen as a barrier to their wide utilization. The increasing grid integration of intermittent renewable energy sources generation significantly changes the scenario of distribution grid operations. Such operational challenges are minimized by the incorporation of the energy storage system, which plays an important role in improving the stability and the reliability of the grid. This study provides the review of the state-of-the-art in the literature on the economic analysis of battery energy storage systems. The paper makes evident the growing interest of batteries as energy storage systems to improve techno-economic viability of renewable energy systems; provides a comprehensive overview of key methodological possibilities for researchers interested in economic analysis of battery energy storage systems; indicates the need to use adequate economic indicators for investment decisions; and identifies key research topics of the analyzed literature: (i) photovoltaic systems with battery energy storage systems for residential areas, (ii) comparison between energy storage technologies, (iii) power quality improvement. The last key contribution is the proposed research agenda.
\end{abstract}

Keywords: energy storage systems; economic feasibility; techno-economic analysis; power quality; renewable energy

\section{Introduction}

Currently, there is an increase in demands for changes in the patterns of energy generation and consumption associated with a search for more sustainable development [1]. Renewable energy sources (RES) can reduce society's dependence on fossil fuels and, as a consequence, reduce greenhouse gas emissions on the environment. More than that, RES can provide energy independence for countries by reducing exposure to the risks associated with high volatility in fossil fuel prices, geopolitical uncertainties, and dependence on these resources [2]. In other words, RES are the best alternatives to meet energy demand, reduce energy costs, and mitigate environmental impacts. The sun is our main source of energy, but only a small portion of that energy is used, and there is potential for new developments. However, sources such as solar and wind energy are said to be intermittent, as they are available or strong only at certain hours of the day, and this is seen as a barrier to their wide and full utilization [3]. 
The increasing grid integration of intermittent RES generation, both distributed generation and utility scale, significantly changes the scenario of distribution network operations [4-6]. Such operational challenges are minimized by the incorporation of the energy storage system (ESS), which plays an important role in improving the stability and the reliability of the grid $[7,8]$. ESS can also play an important role in deregulated markets, for example, by providing arbitrage and increasing the value of RES [4,7]. ESS technologies are constantly being applied to energy systems, performing functions such as grid stabilization, load shifting, grid operational support, power quality improvement, and reliability $[8,9]$.

There are many different energy storage technologies, which are generally categorized as [3,10,11]: electrical, mechanical, electrochemical, thermochemical, chemical, and thermal. Depending on the energy storage and the delivery characteristics, an ESS can serve many roles in an electricity market. According to Ma et al. [3], the ESS in use for electrical energy usually includes electrical, mechanical, and electrochemical types. Due to its versatility, electrochemical systems, of which batteries are the main devices, show greater relevance today [11].

Battery energy storage systems (BESS) are being increasingly used to provide different services to the grid at different voltage levels. In transmission systems, the main services are the support provided through the use of BESS for frequency regulation and during ramp-up or ramp-down operations. In distribution systems, BESS are used to smooth the power provided by intermittent renewable power generation as well as to give the backup energy used to procure virtual inertia through converter-based network interfaces. At a lower scale, BESS are used i0n distributed generation systems to add flexibility to the operational strategies, allowing more time-variable management to follow the objectives considered at the demand side. In all these cases, one of the critical aspects is the cost of the batteries.

In many cases, the investments to set up an efficient BESS for the specific application are too high to be financially efficient for the operator. However, BESS can be also installed in a modular way, adding new components over time, by developing accurate investment plans, provided that such a strategy is found to be profitable for the system operation. Indeed, finding out a convenient investment strategy is a key point for the success of using BESS in grid applications. Then, given the complexity of this application, economic feasibility analysis becomes essential.

Thus, the aim of this study is to provide the review of the state-of-the-art on the literature regarding economic analysis of BESS. It addresses the following research questions (RQ):

RQ1: What are the main characteristics of the literature regarding economic analysis of BESS?

RQ2: What are the main tools and approaches used for the economic analysis of BESS?

RQ3: What are the key paper clusters presented by the referred literature?

RQ4: What are the key research opportunities for this literature?

Therefore, a systematic literature review (SLR) was carried out considering the main studies related to the economic viability of BESS, indicating how these were conducted to assist investment decisions. In addition, no previous reviews were found that presented an insightful discussion on analyzing BESS investments. Thus, our comprehensive SLR on economic analysis of BESS aims to provide guidelines for both researchers and investors.

\section{Materials and Methods}

This section is dedicated to providing key stages followed by the systematic literature review conducted by the present research to address the research questions provided in Section 1. Given the growing number of academic publications worldwide, SLR was chosen as the research method, as it can be useful to appraise, summarize, and communicate results and implications of otherwise unmanageable quantities of research [12]. Systematic literature reviews are different from traditional exploratory reviews, as they are based on replicable, scientific, and transparent processes [13]. The present systematic literature 
review followed a five-step process recommended by the literature [14]: (1) framing questions for the review, (2) identifying relevant work, (3) assessing the quality of the studies, (4) summarizing the evidence, and (5) interpreting the findings. Guidelines from the PRISMA statement were followed throughout these steps when applicable [15].

For Step 1, a general and exploratory literature analysis was performed towards identifying the research questions, as described in Section 1 (Introduction) of the present paper. The four research questions proposed served as guidelines for the following steps. Following, the relevant work was identified (Step 2). For this, Web of Science (maintained by Clarivate Analytics) and Scopus (property of Elsevier) were chosen as databases, given their range of scientific papers and well-known acceptance in the academic sphere. After exploratory attempts, the following search strings were used in these two databases using Boolean logic "AND" between levels (i), (ii), and (iii). The sign ("“") was used to ensure the exact sequence of wording, and the sign $\left(^{*}\right)$ was used to include all variations of the term. For example, the term batter* includes this term both used as singular or plural by the authors.

i Paper title: "economic* feasibility" or "economic* assessment" or "economic* viability" or "economic* analysis" or "economic* evaluation" or "financial feasibility" or "financial assessment" or "financial viability" or "financial analysis" or "financial evaluation" or "techno-economic" or "investment"

ii Paper title: "battery storage" or "energy storage" or "storage system*"

iii Paper title or keywords or abstract: batter*

Figure 1 illustrates the delimitation of the paper sample. The chosen search strings led to 192 publications in the Web of Science and 241 publications from Scopus. These databases were consulted in January 2021. We adopted a rigorous methodology for generating a consistent set of papers, and to increase relevance of conserved publications, only journal articles were included for data extraction, resulting in 125 and 142 papers in each database, respectively. This means that book chapters, conference papers, and other publications that were not included as journal papers were excluded from data analysis. This is justified to increase the review reliability thanks to the peer review process carried out for the assessment of submissions for journal paper publication. As such, we believe that the application of our strategy resulted in a rigorous way to identify a consistent set of selected publications and allowed us to find the main concepts relevant to the analysis of the investments in battery energy storage systems. Considering that the chosen databases include overlapping journals, 136 papers were found as unique papers. This sample was extracted from the databases as electronic spreadsheets to enable Step 3 (assessing the quality of studies).

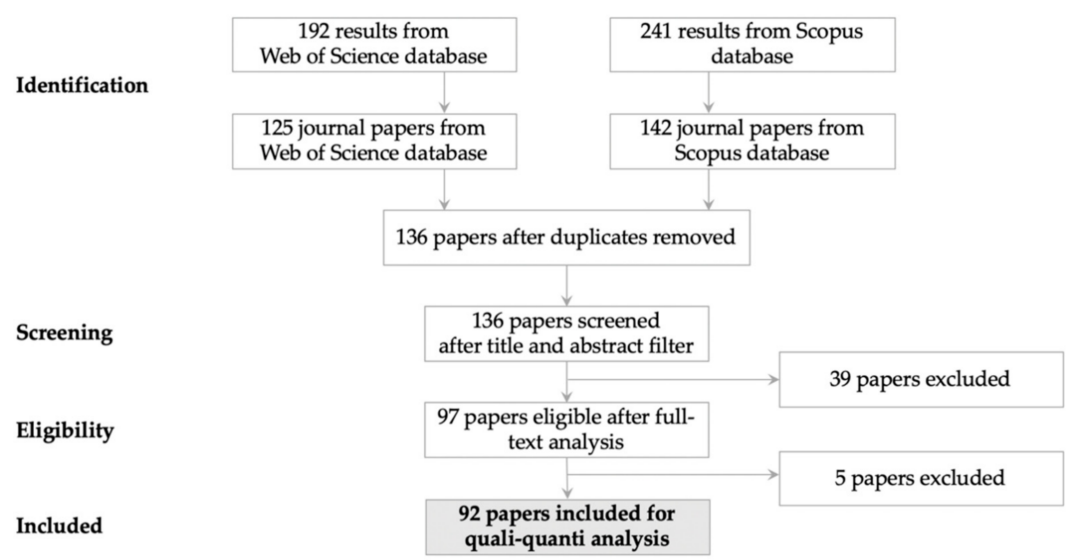

Figure 1. Delimitation of paper sample. Adapted from Moher et al. [15].

For Step 3, eligibility criteria were defined to ensure the sample was adequate to address the research questions. The following inclusion criteria were used: (i) the paper 
included an economic or financial viability analysis or assessment; (ii) the research addressed the BESS as a relevant aspect of this analysis or assessment. Therefore, exclusion criteria considered were: (i) paper did not perform an economic analysis; (ii) paper did not include BESS as key aspect of the research, despite mentioning this term; (iii) paper studied exclusively other energy storage systems (ESS) that are not the battery ones; (iv) paper addressed battery energy storage of electrical vehicles without concern on using it connected to grids or to microgrids. These inclusion and exclusion filters were performed by three of the paper authors sequentially, one after the other, to ensure quality of the final paper sample throughout this refinement process.

This process resulted in a final sample of 92 papers, which were analyzed using both quantitative and qualitative approaches to conduct Steps 4 (summarizing the evidence) and 5 (interpreting the findings).

Figure 2 illustrates the research questions and the associated analyzed aspects. To address RQ1 (what are the main characteristics of the literature regarding economic analysis of BESS?), an electronic spreadsheet organized specific data for each paper. Four characteristics of this literature presented in Section 3.1 were identified considering the paper metadata, including publication year, main journals, keywords network, and number of citations. The keyword network was built with support of VOSViewer software [16], while the other analyses were performed with support of the electronic spreadsheet. Further data were extracted by analyzing the content of each paper, including location of studies and research method. For RQ2 (what are the main tools and methods used for the economic analysis of BESS?), the content analysis was focused on identifying the indicators or the criteria used for the economic analysis, as shown in Section 3.2. The following associated aspects for the methodological choices for the studies were also identified: unit of analysis or scale, type of grid, type of battery, and renewable energy source (RES). To answer RQ3 (what are the key paper clusters presented by the referred literature?), the VOSViewer software [16] was used to support identification of the literature clusters. For this, a network map of the sample provided a visual representation of similarities in terms of bibliographic data. In other words, the papers were organized in the same cluster if they presented a certain degree of similarity in terms of references used to build their studies. The advantage of this network approach was to enable identification of the main research topics addressed by the analyzed literature. Section 3.3 presents this network and describes each paper cluster after content analysis of the papers in the sample. In turn, RQ4 (what are the key research opportunities for this literature?) was answered by deploying a critical analysis derived from answering the previous research questions, as presented in Section 4.

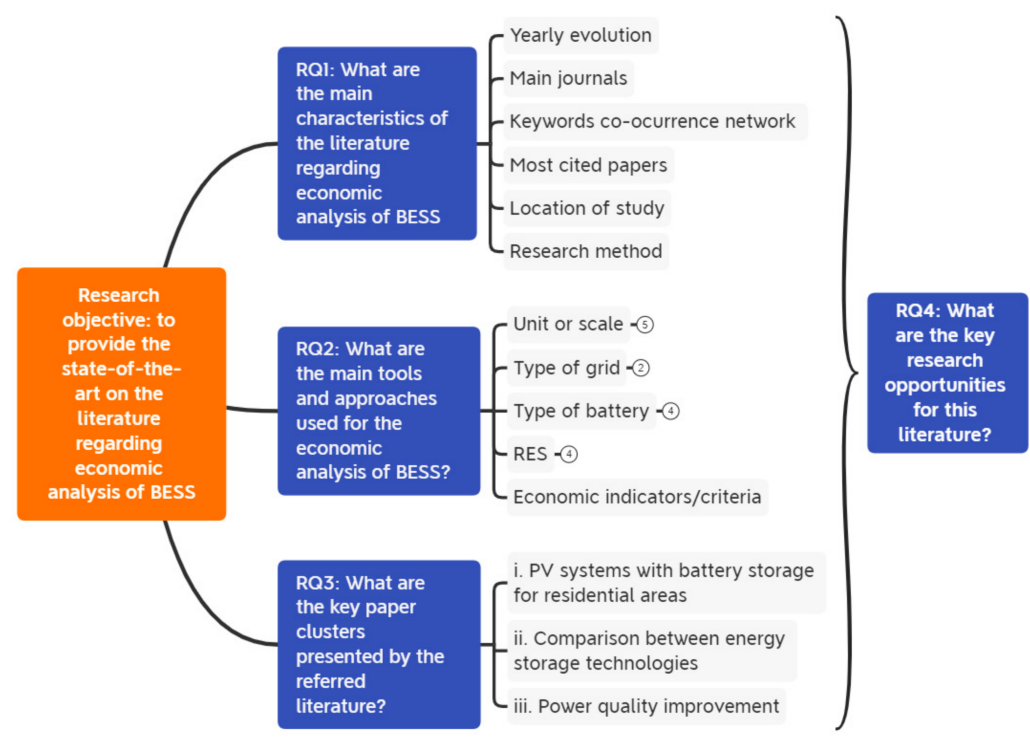

Figure 2. General overview of the research design. 


\section{Results and Discussions}

\subsection{Sample Characterization}

Data analysis started answering RQ1 (what are the main characteristics of the literature regarding economic analysis of BESS?) to provide an initial and general understanding of this literature. Figure 3 shows the yearly distribution of the paper sample (92 articles), indicating growing interest in studies on economic analysis of BESS, especially since 2016. This figure shows a growing number of publications specifically interested in economic analysis of BESS when considering the literature on ESS in general (orange line in Figure 3).

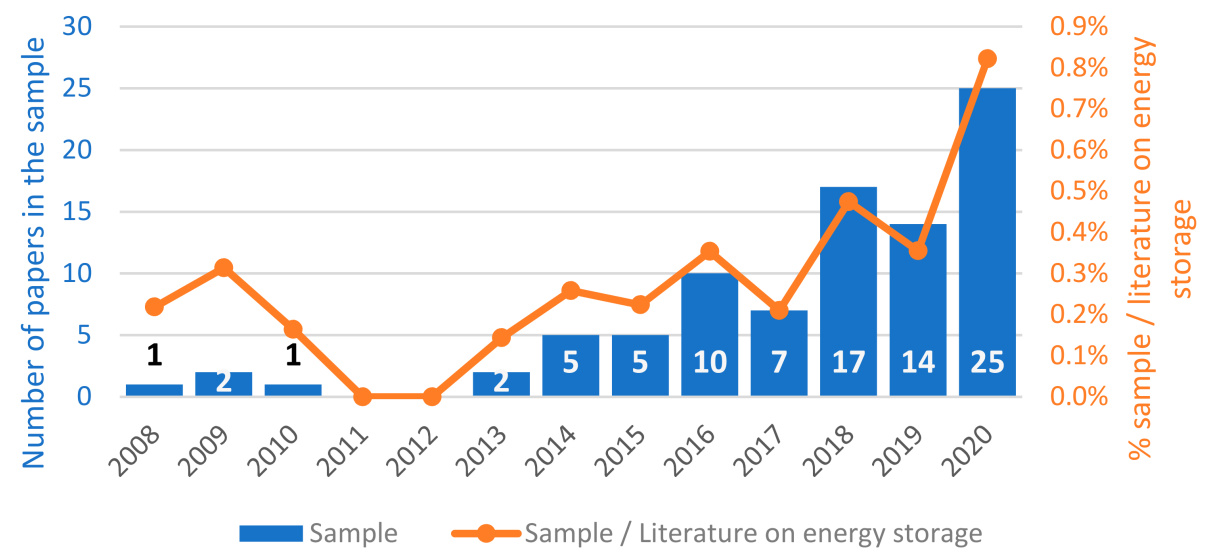

Figure 3. Yearly distribution of paper sample. Note: three early papers published before 2008 are not represented in the figure; these papers were published in 1979, 1985, and 2001.

Figure 4 illustrates journals with at least three papers in the sample. It shows that the three main journals resulting for economic analysis of BESS are Energies, the Journal of Energy Storage, and Applied Energy. There is a clear predominance of journals explicitly addressing the issue of energy from technical and financial approaches, with exception of the Journal of Cleaner Production, which has a broader scope and is not focused only on studies related to the subject of energy.

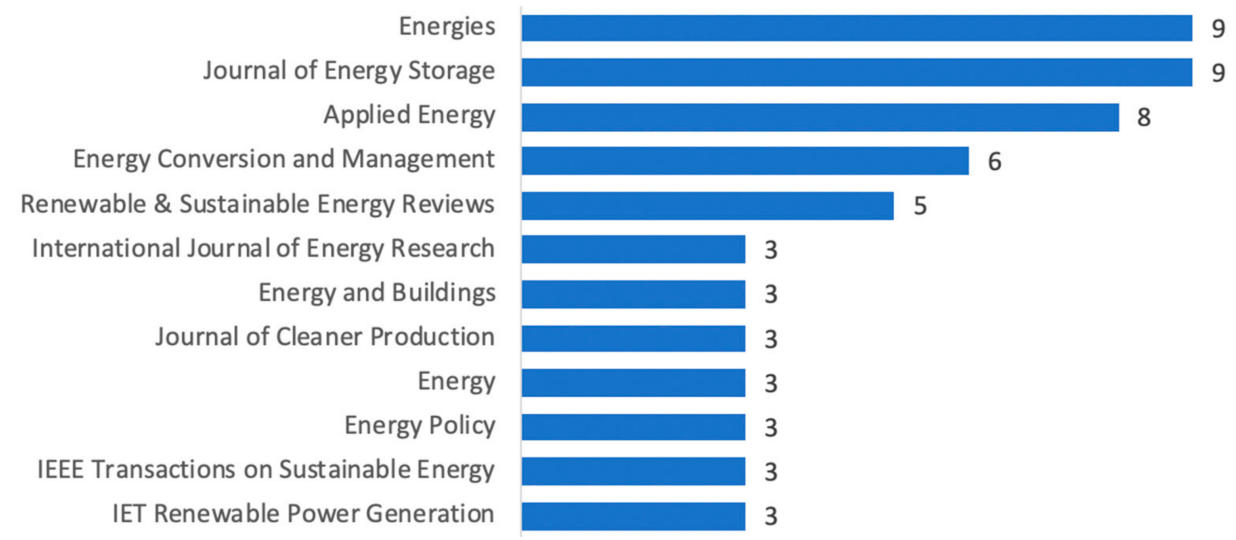

Figure 4. Most frequent journals in the sample.

Figure 5 presents the authors' keywords co-occurrence built using the VOSViewer software [16]. It shows keywords that were used at least three times by the papers in the sample. In this network, node size represents the number of times these keywords were used by the papers, the lines between them indicate that these keywords were used by the same publication, and the colors show the median of the publication year regarding the associated papers. Thus, Figure 5 highlights the relevance of the topics "photovoltaic" and "renewable energy", as they are large nodes, even if they were not used as search strings. 
This network also shows the yellow nodes as possible "hot topics" for the field, as they represent more recent research interests, including tariffs, economic analysis/viability, net present value, and lithium-ion battery.

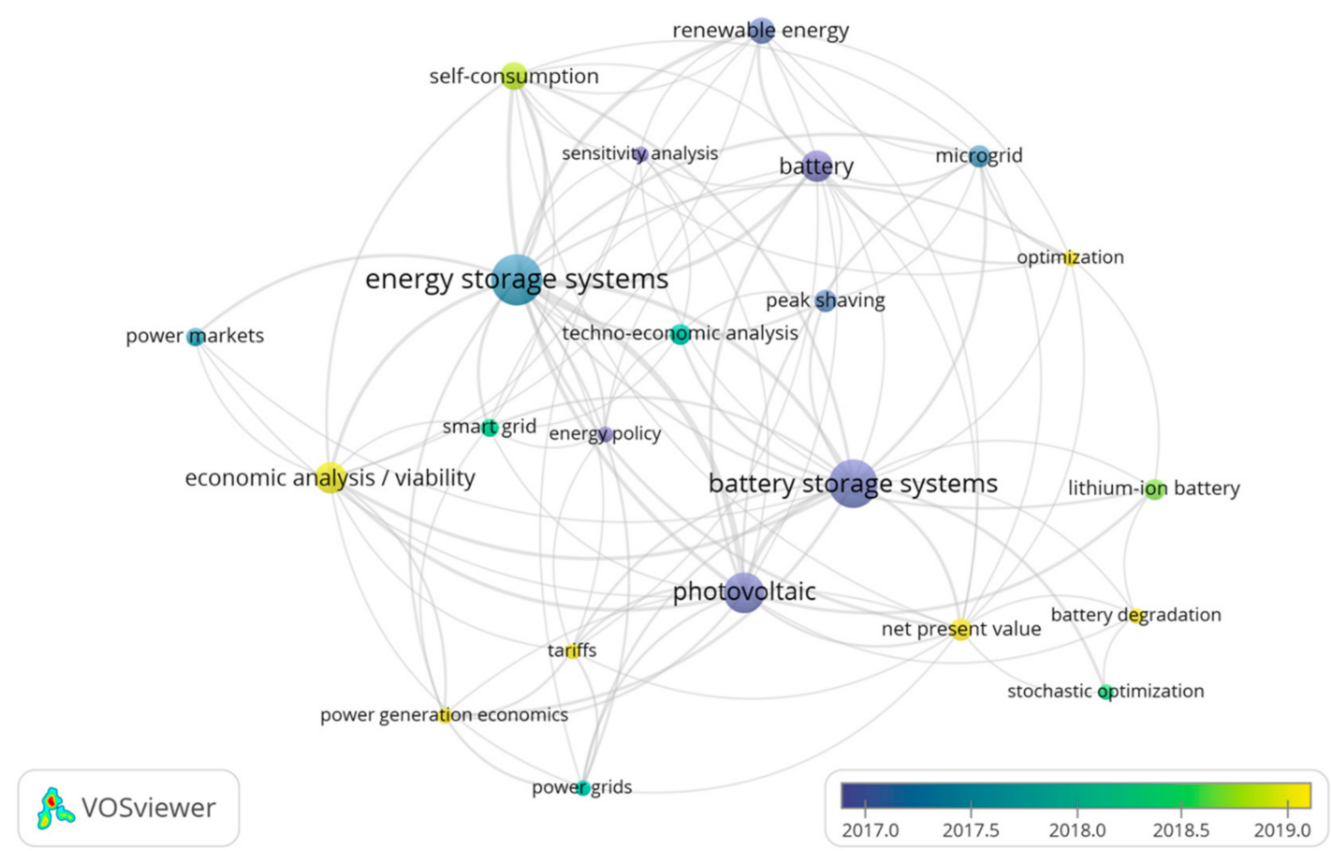

Figure 5. Keywords network. Source: VOSViewer.

The most cited papers in the analyzed sample are listed in Table 1. They include different scope of the economic analysis, such as BESS associated to photovoltaic (PV) or wind RES [17-19], comparison between ESS [20-22], comparison between a system with and without storage system [23], reuse of Li-ion electric vehicle batteries for energy storage systems in stationary settings [24], and demand response programming in the case of component size optimization of a PV/wind RES with ESS [25].

Complementing Table 1, Figure 6 shows the distribution of the most cited papers over time. Even though these ten publications influence the literature, there are some trends that can be identified. For instance, although Diaf et al. [18] and Kaldellis et al. [21] have high absolute number of citations, Figure 6 provides a tendency that these publications may relatively reduce their influence on more recent publication given percentage decrease of citations over the years. On the other hand, Hoppmann et al. [17] seems to be still influential also in recent publications. Despite being more recent, Amrollahi and Bathaee [25] also shows relevant influence in the academic publications, as it is relatively highly cited by recent publications.

Figure 7 brings the distribution of studies in terms of countries. The content analysis of the paper sample identified the location chosen by the researchers to perform the economic analysis of systems involving BESS. Most frequent countries are Italy (nine papers), United Kingdom (nine papers), China (eight papers), United States (seven papers), Germany (six papers), and Greece (five papers). This concentration of publications in Europe, USA, and China indicates opportunity for more studies in other locations. Interesting insights can emerge from studies on context specific factors influencing economic viability of energy systems integrated to BESS as well as on comparison between factors associated with different locations. 
Table 1. Summary table of the most cited articles in the analyzed sample.

\begin{tabular}{|c|c|c|}
\hline Authors (Year) & $\begin{array}{c}\text { Citations } \\
\text { (Citation/Year) }\end{array}$ & Summary \\
\hline Hoppmann et al. (2014) [17] & $\begin{array}{c}248 \\
(35.4)\end{array}$ & $\begin{array}{l}\text { The study proposes a simulation model that investigates the economic viability of } \\
\text { BESS for residential PV in Germany under eight different electricity price scenarios } \\
\text { from } 2013 \text { to 2022. The authors also provide a review of previous studies analyzing } \\
\text { the economics of integrated PV-battery systems. }\end{array}$ \\
\hline Bradbury et al. (2014) [20] & $\begin{array}{c}158 \\
(22.6)\end{array}$ & $\begin{array}{l}\text { The study investigates } 14 \text { types of ESS towards identifying ESS power and capacities } \\
\text { that maximize the internal rate of return (IRR) based on price arbitrage potential in } \\
\text { real-time U.S. electricity markets. For this, it shows the results of a linear } \\
\text { optimization model. }\end{array}$ \\
\hline Diaf et al. (2008) [18] & $\begin{array}{c}149 \\
(11.5)\end{array}$ & $\begin{array}{l}\text { The paper provides a technical and economic assessment of hybrid PV/wind } \\
\text { stand-alone system with BESS in Corsica island (France). For this, it uses the } \\
\text { levelized cost of energy (LCOE), as economic submodel, together with system } \\
\text { components submodel and technical submodel based on loss of power } \\
\text { supply probability. }\end{array}$ \\
\hline Kaldellis et al. (2009) [21] & $\begin{array}{c}145 \\
(12.1)\end{array}$ & $\begin{array}{l}\text { The study conducts a technical and economic assessment to compare various RES } \\
\text { and ESS configurations in the Aegean Archipelago Islands (Greece), supported by } \\
\text { the supplementary or back-up use of existing thermal units. }\end{array}$ \\
\hline Ma et al. (2014) [3] & $\begin{array}{c}143 \\
(20.4)\end{array}$ & $\begin{array}{l}\text { The study compares two energy storage technologies, batteries and pumped hydro } \\
\text { storage, for the power supply on an island in Hong Kong based on off-grid } \\
\text { renewable energy storage. Life cycle costs analysis (LCCA), levelized costs for the } \\
\text { renewable energy storage system, and the LCCA ratios between four scenarios are } \\
\text { calculated and compared. }\end{array}$ \\
\hline Heymans et al. (2014) [24] & $\begin{array}{c}114 \\
(16.3)\end{array}$ & $\begin{array}{l}\text { The authors conduct an economic analysis of the reuse of Li-ion EV batteries for ESS } \\
\text { in stationary settings, applying a Matlab simulation of a residential energy profile } \\
\text { and regulated cost structure. }\end{array}$ \\
\hline $\begin{array}{l}\text { Amrollahi and Bathaee (2017) } \\
\text { [25] }\end{array}$ & $\begin{array}{c}105 \\
(26.3)\end{array}$ & $\begin{array}{l}\text { The study investigates demand response programs in the case of component size } \\
\text { optimization of a hybrid PV/wind generation together with ESS in a stand-alone } \\
\text { micro-grid. It considers component size optimization and relevant costs reduction. }\end{array}$ \\
\hline Zheng et al. (2015) [22] & $\begin{array}{c}79 \\
(13.2)\end{array}$ & $\begin{array}{l}\text { The study provides economic analysis of a range of storage technologies for peak } \\
\text { shaving demand response under a realistic tariff (Con Edison, New York) in the } \\
\text { context of US households. }\end{array}$ \\
\hline $\begin{array}{c}\text { Dufo-Lopez and } \\
\text { Bernal-Agustin (2015) [23] }\end{array}$ & $\begin{array}{c}71 \\
(11.8)\end{array}$ & $\begin{array}{l}\text { This paper evaluates a grid-connected system with storage under a time-of-use } \\
\text { electricity tariff. It analyzes the total net present cost (NPC) of a system with storage } \\
\text { and compares it with a system without storage. }\end{array}$ \\
\hline Uddin et al. (2017) [19] & $\begin{array}{c}65 \\
(16.3)\end{array}$ & $\begin{array}{l}\text { Collecting data of a coupled PV lithium-ion (Li-ion) battery system of a mid-sized } \\
\text { UK family home for more than a year, the paper presents a cost-benefit analysis of } \\
\text { this system considering also the battery degradation during fifty } \\
\text { long-term experiments. }\end{array}$ \\
\hline
\end{tabular}

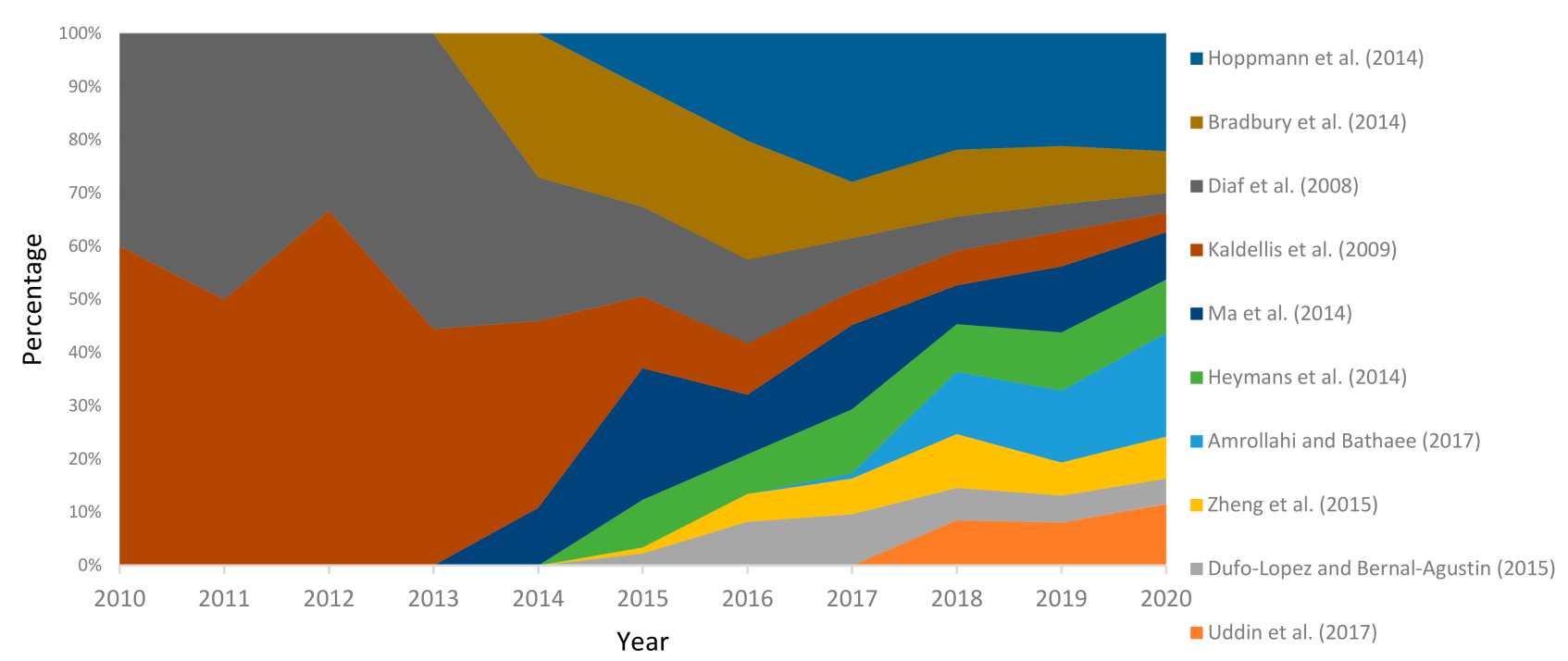

Figure 6. Distribution of citations of most cited papers. 


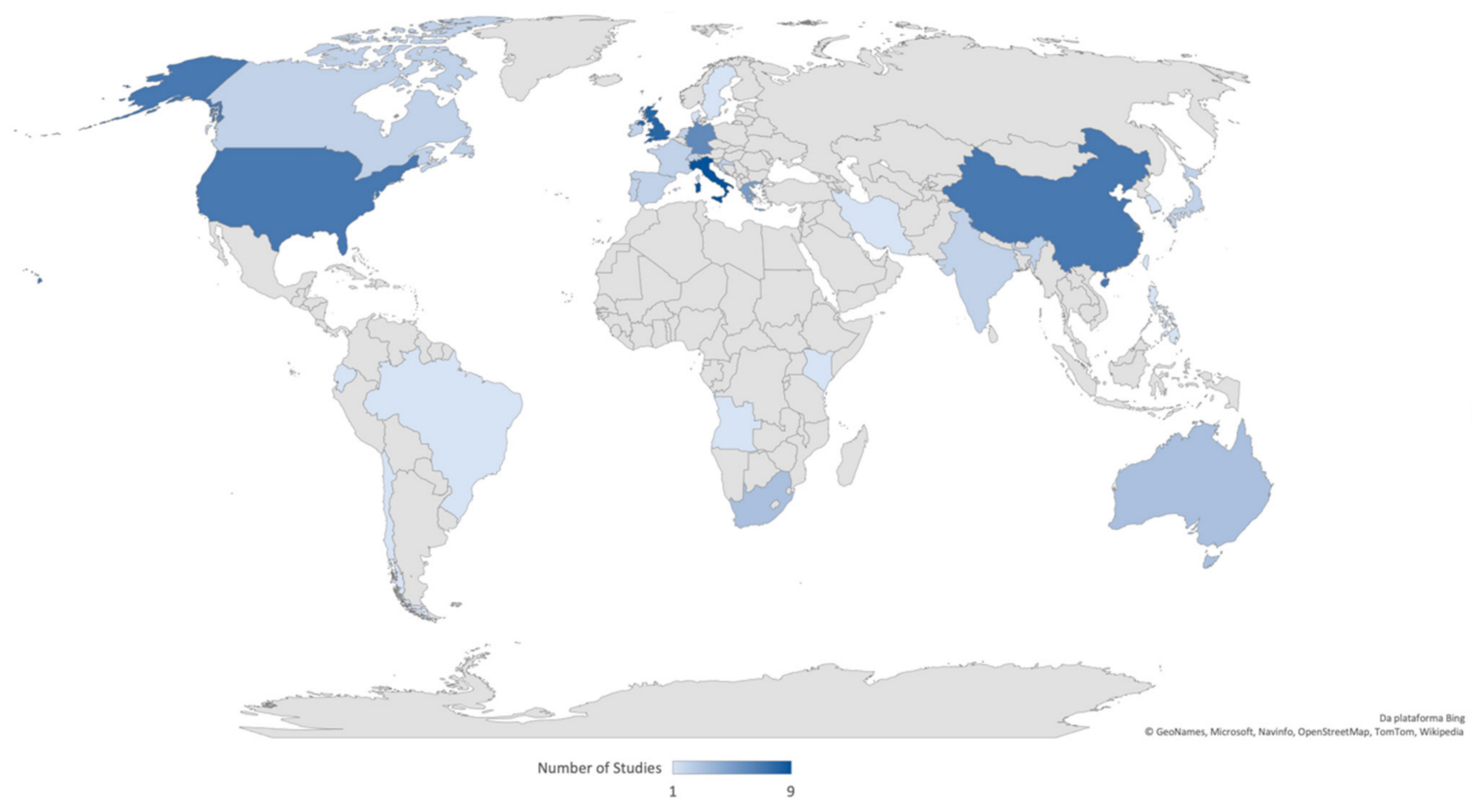

Figure 7. Number of studies by analyzed countries.

Still in terms of literature characterization, the content analysis also indicated the most frequent research methods used by the paper sample (Figure 8). Mathematical modelling seems to be the most preferred method by the researchers (86 papers, corresponding to $93.5 \%$ of the paper sample), which can be combined with simulation (55 papers), optimization (49 papers), or both (35 papers).

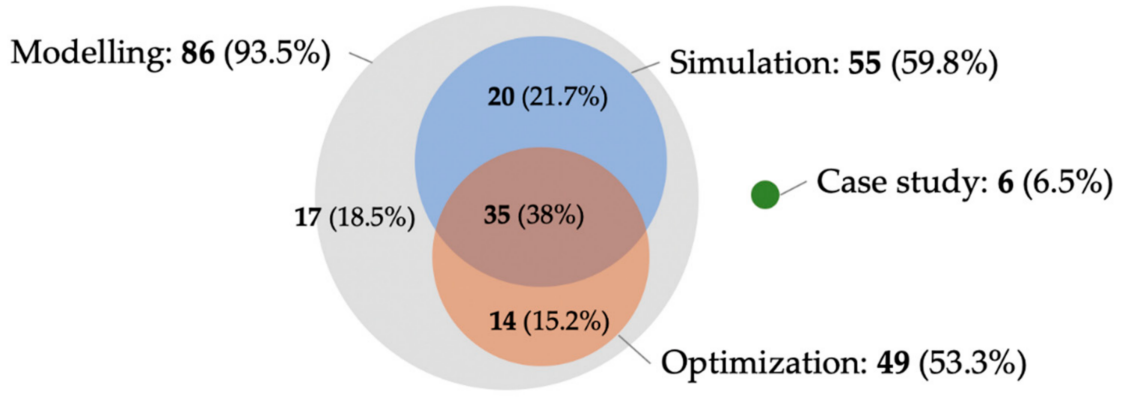

Figure 8. Number of papers using each method and associated percentages.

\subsection{Indicators and Criteria Used for the Economic Analysis of BESS}

This section aims to answer RQ2 (what are the main tools and approaches used for the economic analysis of BESS?). For this, relevant information about the analyzed studies was extracted and summarized in Table 2. It is interesting to note that the unit of analysis is a key methodological decision for studies interested in the economic analysis of BESS, influencing choices in terms of tools and methods used for this purpose. Thus, Table 2 was organized according to the unit or the scale, which followed classification previously used by the literature [26]: (A) non-domestic, (B) residential, (C) commercial and industrial, (D) region/community, (E) utility scale. Figure 9 presents the evolution of the studies over the years based on the unit or the scale. 
Table 2. Summary table of technologies, sources, and approaches used in the feasibility analysis.

\begin{tabular}{|c|c|c|c|c|c|c|c|c|c|c|c|c|}
\hline \multirow{2}{*}{ Articles } & \multirow{2}{*}{ Unit } & \multirow{2}{*}{ Grid } & \multirow{2}{*}{$\begin{array}{c}\text { Type } \\
\text { Batteries }\end{array}$} & \multirow{2}{*}{ RES } & \multicolumn{8}{|c|}{ Economic Indicators/Criteria } \\
\hline & & & & & NPV & NPC/LCCA & IRR & PB & DPB & EAC & $\mathrm{LCOE}$ & Others \\
\hline Aderemi et al. [28] & A & 1 & unspecified & PV & & NPC & & & & & LCOE & \\
\hline Heymans et al. [24] & B & 2 & $\begin{array}{l}\text { Li-ion } \\
\text { (reused) }\end{array}$ & $\mathrm{PV} /$ wind & & & & & & EAC & & $\mathrm{O}$ \\
\hline $\begin{array}{c}\text { Hoppmann et al. } \\
{[17]}\end{array}$ & B & 2 & Lead-acid & PV & NPV & & & & & & & \\
\hline Kantor et al. [29] & B & 2 & $\begin{array}{c}\text { Li-ion } \\
\text { (comparison) }\end{array}$ & unspecified & & & & & & EAC & & \\
\hline Zheng et al. [22] & B & 2 & $\begin{array}{c}\text { various } \\
\text { (comparison) }\end{array}$ & unspecified & & & & & & EAC & LCOE & \\
\hline Cucchiella et al. [30] & B & 2 & Lead-acid & PV & NPV & & & & & & & \\
\hline Parra et al. [31] & B & 2 & $\begin{array}{c}\text { Lead-acid, } \\
\text { Li-ion } \\
\text { (comparison) }\end{array}$ & PV & & & IRR & & & & LCOE & $\mathrm{O}$ \\
\hline $\begin{array}{c}\text { Amrollahi and } \\
\text { Bathaee [25] }\end{array}$ & B & 1 & unspecified & $\mathrm{PV} /$ wind & & NPC & & & & EAC & & \\
\hline Cucchiella et al. [32] & B & 2 & Lead-acid & PV & NPV & & & & & & & \\
\hline Hemmati [33] & B & 1,2 & Li-ion & Wind & & & & & & EAC & & MCS \\
\hline Uddin et al. [19] & B & 2 & Li-ion & PV & & & & PB & & & & $\mathrm{O}$ \\
\hline Barcellona et al. [34] & B & 2 & $\begin{array}{c}\text { Lead-acid, } \\
\text { Li-ion } \\
\text { (comparison) }\end{array}$ & PV & & & & & & EAC & & $\mathrm{O}$ \\
\hline Carrico et al. [35] & B & 1 & Li-ion & PV & & & & & & & & $\mathrm{O}$ \\
\hline Cucchiella et al. [36] & B & 2 & Lead-acid & PV & NPV & & & & & & & \\
\hline Masebinu et al. [37] & B & 2 & unspecified & unspecified & NPV & NPC & & & & & LCOE & MCS \\
\hline Tervo et al. [38] & B & 2 & Li-ion & PV & & & & & & & LCOE & \\
\hline $\begin{array}{l}\text { Van der Stelt et al. } \\
\text { [39] }\end{array}$ & B & 2 & Li-ion & PV & & & & PB & & & LCOE & \\
\hline $\begin{array}{l}\text { Von Appen and } \\
\text { Braun [40] }\end{array}$ & B & 2 & unspecified & PV & & & & & & & & $\mathrm{O}$ \\
\hline Oliva et al. [41] & B & 2 & Li-ion & PV & NPV & & & PB & & & & \\
\hline Dong et al. [42] & B & 2 & Li-ion & PV & & & & PB & & & & \\
\hline Foles et al. [43] & B & 1,2 & Li-ion & PV & NPV & & IRR & PB & & & LCOE & $\mathrm{O}$ \\
\hline Nousdilis et al. [44] & B & 2 & Li-ion & PV & NPV & & IRR & & & & & \\
\hline $\begin{array}{l}\text { Shaw-Williams et al. } \\
\text { [45] }\end{array}$ & B & 2 & Li-ion & PV & NPV & & & & & & & MCS \\
\hline Wang et al. [46] & B & 2 & Li-ion & PV & NPV & & & & DPB & & & \\
\hline Pereira et al. [47] & B & 1 & Li-ion & PV & & & & PB & & & & $\mathrm{O}$ \\
\hline Deotti et al. [48] & B & 2 & Li-ion & PV & NPV & & IRR & PB & & & & \\
\hline $\begin{array}{l}\text { Dufo-Lopez and } \\
\text { Bernal-Agustin [23] }\end{array}$ & $\mathrm{B}, \mathrm{C}$ & 2 & $\begin{array}{c}\text { Lead-acid, } \\
\text { Li-ion } \\
\text { (comparison) }\end{array}$ & unspecified & NPV & NPC & & & & & LCOE & \\
\hline Dumont et al. [49] & $\mathrm{B}, \mathrm{C}$ & 2 & Li-ion & PV & & & & PB & & & & \\
\hline Al-Foraih et al. [50] & $\mathrm{B}, \mathrm{C}$ & 2 & $\begin{array}{c}\text { various } \\
\text { (comparison) }\end{array}$ & unspecified & NPV & & & PB & & & & \\
\hline $\begin{array}{c}\text { Tohidi and Gibescu } \\
\text { [51] }\end{array}$ & $\mathrm{B}, \mathrm{C}$ & 2 & Flow & PV & & & & & & EAC & & \\
\hline Gagliano et al. [52] & $\mathrm{B}, \mathrm{C}$ & 2 & Li-ion & PV & NPV & & IRR & PB & $\mathrm{DPB}$ & & & \\
\hline Yan et al. [53] & $\mathrm{C}$ & 2 & $\begin{array}{c}\text { various } \\
\text { (comparison) }\end{array}$ & unspecified & NPV & & IRR & $\mathrm{PB}$ & & & & \\
\hline
\end{tabular}


Table 2. Cont.

\begin{tabular}{|c|c|c|c|c|c|c|c|c|c|c|c|c|}
\hline \multirow{2}{*}{ Articles } & \multirow{2}{*}{ Unit } & \multirow{2}{*}{ Grid } & \multirow{2}{*}{$\begin{array}{c}\text { Type } \\
\text { Batteries }\end{array}$} & \multirow{2}{*}{ RES } & \multicolumn{8}{|c|}{ Economic Indicators/Criteria } \\
\hline & & & & & NPV & NPC/LCCA & IRR & PB & DPB & EAC & LCOE & Others \\
\hline Barberis et al. [54] & $\mathrm{C}$ & 1,2 & $\begin{array}{c}\text { various } \\
\text { (comparison) }\end{array}$ & $\begin{array}{c}\text { Solar } \\
\text { (hybrid) }\end{array}$ & & & & & & & & $\mathrm{O}$ \\
\hline Liao et al. [55] & $\mathrm{C}$ & 2 & $\mathrm{NaS}$ & unspecified & & & & PB & & & & $\mathrm{O}$ \\
\hline Pandzic [56] & $\mathrm{C}$ & 2 & $\begin{array}{l}\text { various } \\
\text { (hybrid) }\end{array}$ & unspecified & & & & & & & & $\begin{array}{l}\mathrm{O}, \\
\mathrm{MCS}\end{array}$ \\
\hline Liao et al. [57] & $\mathrm{C}$ & 2 & $\begin{array}{c}\text { various } \\
\text { (comparison) }\end{array}$ & PV & NPV & & & & & & & $\mathrm{O}$ \\
\hline Beltran et al. [58] & $\mathrm{C}$ & 1 & $\begin{array}{c}\text { Li-ion } \\
\text { (comparison) }\end{array}$ & Wind & & & & & & & & $\mathrm{O}$ \\
\hline $\begin{array}{l}\text { Martinez-Bolanos } \\
\text { et al. [59] }\end{array}$ & $\mathrm{C}$ & 2 & $\begin{array}{c}\text { various } \\
\text { (comparison) }\end{array}$ & unspecified & NPV & & & & & & & $\mathrm{O}$ \\
\hline Rallo et al. [60] & $\mathrm{C}$ & 2 & $\begin{array}{l}\text { Li-ion } \\
\text { (reused) }\end{array}$ & unspecified & & & & & & & & $\mathrm{O}$ \\
\hline Tsai et al. [61] & $\mathrm{C}$ & 2 & Li-ion & unspecified & & NPC & IRR & & DPB & & LCOE & $\mathrm{O}$ \\
\hline Diaf et al. [18] & $\mathrm{D}$ & 1 & unspecified & PV/wind & NPV & & & & & & LCOE & \\
\hline Kaldellis et al. [21] & $\mathrm{D}$ & 1 & $\begin{array}{c}\text { various } \\
\text { (comparison) }\end{array}$ & unspecified & & & & & & & & $\mathrm{O}$ \\
\hline Koutroulis et al. [62] & $\mathrm{D}$ & 1 & Lead-acid & Wind & NPV & & IRR & & DPB & & & $\mathrm{O}$ \\
\hline $\begin{array}{l}\text { Papadopoulos and } \\
\text { Maltas [63] }\end{array}$ & $\mathrm{D}$ & 1 & unspecified & $\begin{array}{c}\text { PV } \\
\text { (hybrid) }\end{array}$ & NPV & NPC & IRR & PB & & & LCOE & $\mathrm{O}$ \\
\hline Ren et al. [64] & $\mathrm{D}$ & 1 & $\begin{array}{c}\text { Flow } \\
\text { (comparison) }\end{array}$ & $\mathrm{PV} /$ wind & & & & & & EAC & & \\
\hline Ma et al. [3] & $\mathrm{D}$ & 1 & $\begin{array}{c}\text { Li-ion, } \\
\text { Lead-acid } \\
\text { (comparison) }\end{array}$ & $\mathrm{PV} /$ wind & & NPC & & & & & LCOE & \\
\hline Soberanis et al. [65] & $\mathrm{D}$ & 1 & Flow & $\begin{array}{l}\text { PV/wind } \\
\text { (hybrid) }\end{array}$ & & NPC & & & & & & $\mathrm{O}$ \\
\hline Bai et al. [66] & $\mathrm{D}$ & 2 & $\begin{array}{l}\text { Li-ion } \\
\text { (reused) }\end{array}$ & PV & NPV & & & & & & LCOE & \\
\hline $\begin{array}{l}\text { Chagnard and } \\
\text { Francois [67] }\end{array}$ & $\mathrm{D}$ & 1 & Li-ion & PV & NPV & & IRR & & DPB & & & $\mathrm{O}$ \\
\hline Chiacchio et al. [68] & $\mathrm{D}$ & 2 & Li-ion & PV & NPV & & & & DPB & & & MCS \\
\hline Esparcia et al. [69] & $\mathrm{D}$ & 1 & $\begin{array}{c}\text { Li-ion } \\
\text { (comparison) }\end{array}$ & $\begin{array}{c}\text { PV } \\
\text { (hybrid) }\end{array}$ & & & & & & & LCOE & \\
\hline $\begin{array}{c}\text { Gbadegesin et al. } \\
{[70]}\end{array}$ & $\mathrm{D}$ & 1 & $\begin{array}{c}\text { Lead-acid, } \\
\text { Li-ion } \\
\text { (comparison) }\end{array}$ & $\begin{array}{l}\text { PV/wind } \\
\text { (hybrid) }\end{array}$ & & & & & & & LCOE & \\
\hline $\begin{array}{c}\text { Lata-Garcia et al. } \\
{[71]}\end{array}$ & $\mathrm{D}$ & 1 & $\begin{array}{c}\text { various } \\
\text { (comparison) }\end{array}$ & PV/Hydro & & NPC & & & & EAC & LCOE & \\
\hline Lorenzi et al. [72] & $\mathrm{D}$ & 1 & $\begin{array}{l}\text { Li-ion, Flow } \\
\text { (comparison) }\end{array}$ & Various & NPV & & & & DPB & & & \\
\hline Iliadis et al. [73] & $\mathrm{D}$ & 1 & Li-ion & $\begin{array}{l}\text { PV/wind } \\
\text { (hybrid) }\end{array}$ & NPV & & & & & & LCOE & $\mathrm{O}$ \\
\hline Kelly and Leahy [74] & $\mathrm{D}$ & 2 & Li-ion & PV/wind & & & & & & & & $\mathrm{O}$ \\
\hline Kelly and Leahy [75] & $\mathrm{D}$ & 1 & Li-ion & unspecified & NPV & & & & & & & $\mathrm{RO}$ \\
\hline Kiptoo et al. [76] & $\mathrm{D}$ & 1,2 & $\begin{array}{c}\text { Li-ion } \\
\text { (comparison) }\end{array}$ & $\mathrm{PV} /$ wind & & & & & & EAC & & \\
\hline $\begin{array}{l}\text { Krishnamoorthy } \\
\text { et al. [77] }\end{array}$ & $\mathrm{D}$ & 1 & $\begin{array}{c}\text { various } \\
\text { (comparison) }\end{array}$ & PV/biomass & & NPC & & & & & LCOE & \\
\hline Shabani et al. [78] & $\mathrm{D}$ & 1 & $\begin{array}{c}\text { Lead-acid } \\
\text { (comparison) }\end{array}$ & $\mathrm{PV} /$ wind & & NPC & & & & & LCOE & \\
\hline
\end{tabular}


Table 2. Cont.

\begin{tabular}{|c|c|c|c|c|c|c|c|c|c|c|c|c|}
\hline \multirow{2}{*}{ Articles } & \multirow{2}{*}{ Unit } & \multirow{2}{*}{ Grid } & \multirow{2}{*}{$\begin{array}{c}\text { Type } \\
\text { Batteries }\end{array}$} & \multirow{2}{*}{ RES } & \multicolumn{8}{|c|}{ Economic Indicators/Criteria } \\
\hline & & & & & NPV & NPC/LCCA & IRR & PB & DPB & EAC & LCOE & Others \\
\hline Li et al. [79] & $\mathrm{D}, \mathrm{E}$ & 2 & $\begin{array}{c}\text { various } \\
\text { (comparison) }\end{array}$ & $\mathrm{PV} /$ wind & & & & PB & & & & $\mathrm{O}$ \\
\hline Sobieski et al. [80] & E & 2 & unspecified & unspecified & NPV & & & & & & & \\
\hline Su et al. [81] & $\mathrm{E}$ & 1,2 & unspecified & PV & NPV & & IRR & PB & & & & \\
\hline $\begin{array}{c}\text { Rudolf and } \\
\text { Papastergiou [82] }\end{array}$ & E & 2 & $\begin{array}{l}\text { NaS, Li-ion } \\
\text { (comparison) }\end{array}$ & PV & NPV & & & & & & & \\
\hline Bradbury et al. [20] & $\mathrm{E}$ & 2 & $\begin{array}{c}\text { various } \\
\text { (comparison) }\end{array}$ & unspecified & & & IRR & & & & & \\
\hline $\begin{array}{c}\text { Fathima and } \\
\text { Palanisamy [27] }\end{array}$ & $\mathrm{E}$ & 2 & $\begin{array}{c}\text { various } \\
\text { (comparison) }\end{array}$ & $\begin{array}{l}\mathrm{PV} / \text { wind } \\
\text { (hybrid) }\end{array}$ & NPV & & & $\mathrm{PB}$ & DPB & EAC & & $\mathrm{O}$ \\
\hline Han et al. [83] & $\mathrm{E}$ & 2 & $\begin{array}{c}\text { various } \\
\text { (comparison) }\end{array}$ & unspecified & & & & & & & & $\mathrm{O}$ \\
\hline Bakke et al. [84] & E & 2 & Li-ion & unspecified & NPV & & & PB & & & & $\mathrm{RO}$ \\
\hline Maghouli et al. [85] & E & 2 & Lead-acid & Wind & & & & & & EAC & & $\mathrm{O}$ \\
\hline Quaia [86] & E & 2 & $\begin{array}{l}\text { various } \\
\text { (hybrid) }\end{array}$ & PV & NPV & & & PB & & & & \\
\hline Quaia [87] & E & 2 & $\begin{array}{l}\text { various } \\
\text { (hybrid) }\end{array}$ & PV & NPV & & & PB & & & & \\
\hline Tamura [88] & E & 2 & $\begin{array}{c}\text { Lead-acid, } \\
\text { Li-ion } \\
\text { (comparison) }\end{array}$ & unspecified & & & & & & & & $\mathrm{O}$ \\
\hline $\begin{array}{l}\text { Thompson et al. } \\
\text { [89] }\end{array}$ & E & 2 & unspecified & unspecified & & & & & & & & $\begin{array}{c}\mathrm{O}, \\
\mathrm{MCS}\end{array}$ \\
\hline Lin and $\mathrm{Wu}[90]$ & E & 2 & $\begin{array}{c}\text { various } \\
\text { (comparison) }\end{array}$ & unspecified & NPV & & & & & & & $\mathrm{O}$ \\
\hline Fleer et al. [91] & E & 2 & Li-ion & unspecified & NPV & & & & & & & \\
\hline Pandzic [92] & E & 2 & unspecified & Wind & & & & & & EAC & & $\mathrm{O}$ \\
\hline Perkins [93] & E & 2 & Li-ion & PV/biomass & & & & & & & LCOE & \\
\hline Sevilla et al. [94] & E & 2 & Li-ion & PV & NPV & & & & & & LCOE & $\mathrm{O}$ \\
\hline $\begin{array}{c}\text { Efthymiou et al. } \\
\text { [95] }\end{array}$ & E & 2 & Li-ion & unspecified & NPV & & IRR & & DPB & & & $\mathrm{O}$ \\
\hline Zurita et al. [96] & $\mathrm{E}$ & 2 & Li-ion & PV/Solar & & & & & & & LCOE & \\
\hline $\begin{array}{c}\text { Ehsan and Yang } \\
\text { [97] }\end{array}$ & E & 2 & unspecified & $\mathrm{PV} /$ wind & NPV & & & & & & & MCS \\
\hline Engels et al. [98] & E & 2 & Li-ion & unspecified & NPV & & & PB & & & & MCS \\
\hline Kim et al. [99] & E & 2 & Flow & unspecified & & & & & & & & $\mathrm{O}$ \\
\hline $\begin{array}{l}\text { Bahloul and } \\
\text { Khadem [100] }\end{array}$ & $\mathrm{E}$ & 2 & $\begin{array}{l}\text { Li-ion } \\
\text { (hybrid) }\end{array}$ & unspecified & & & & & & EAC & & $\mathrm{O}$ \\
\hline Jumare [101] & E & 2 & $\mathrm{NaS}$ & unspecified & NPV & & IRR & PB & DPB & & & \\
\hline Mostafa et al. [102] & E & 2 & $\begin{array}{c}\text { various } \\
\text { (comparison) }\end{array}$ & unspecified & & & & & & EAC & LCOE & $\mathrm{O}$ \\
\hline Raugei et al. [103] & $\mathrm{E}$ & 2 & Li-ion & PV & & & & & & & & $\mathrm{O}$ \\
\hline Sun et al. [104] & $\mathrm{E}$ & 2 & Li-ion & Thermal & & & & PB & & & & \\
\hline Rawa et al. [105] & E & 2 & $\mathrm{NaS}$ & PV/wind & & & & & & & & $\mathrm{O}$ \\
\hline $\begin{array}{c}\text { Kirli and Kiprakis } \\
\text { [106] }\end{array}$ & $\mathrm{E}$ & 2 & $\begin{array}{c}\text { various } \\
\text { (comparison) }\end{array}$ & unspecified & NPV & & & PB & & & LCOE & $\mathrm{O}$ \\
\hline Pavic et al. [107] & various & 2 & Li-ion & unspecified & NPV & & & & & & & \\
\hline $\begin{array}{c}\text { Davitian and Leigh } \\
\text { [108] }\end{array}$ & $\begin{array}{l}\text { unspe- } \\
\text { cified }\end{array}$ & $\begin{array}{l}\text { unspe- } \\
\text { cified }\end{array}$ & unspecified & unspecified & & & & & & EAC & & \\
\hline & Num & ber of $p$ & pers & & 42 & 11 & 14 & 23 & 10 & 17 & 24 & 47 \\
\hline
\end{tabular}




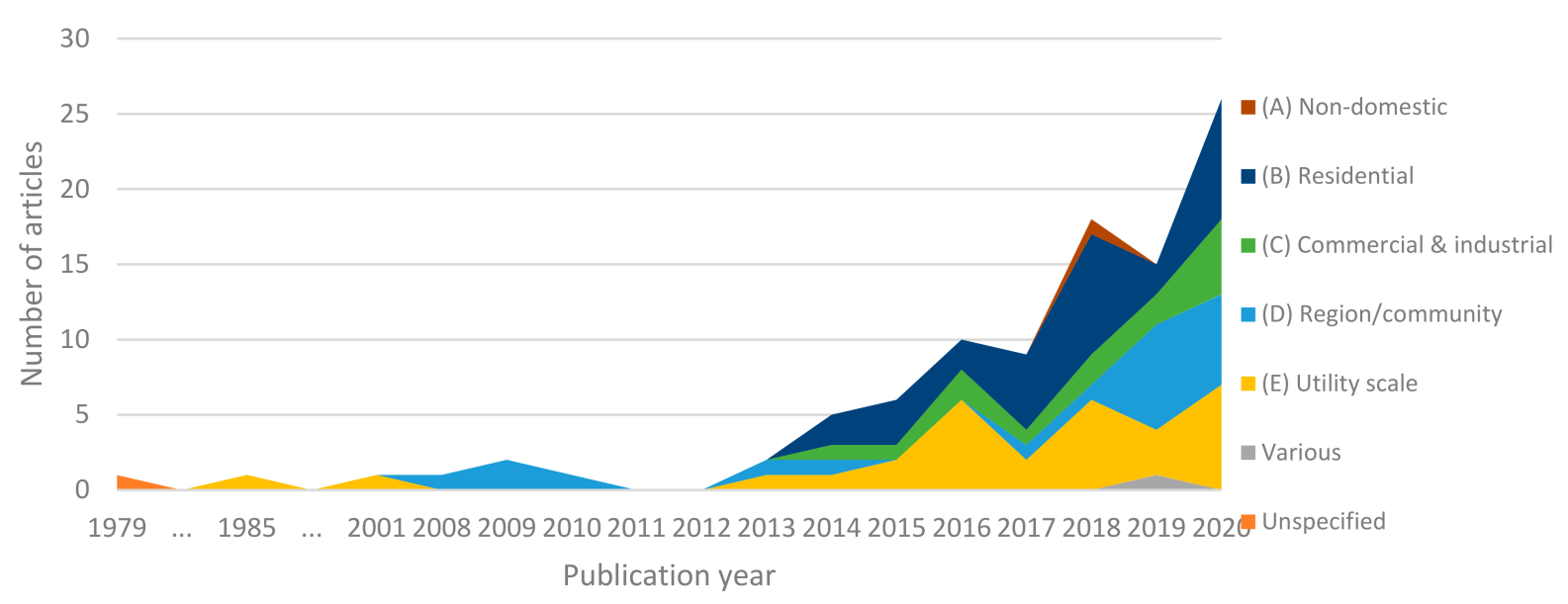

Figure 9. Distribution of studies over the years based on the unit or the scale.

In addition to the unit or the scale, Table 2 identifies the mode of the electrical system analyzed ((1) off grid, (2) grid connected), the types of batteries evaluated (lead-acid, sodium-sulfur (NaS), lithium-ion (Li-ion), and flow batteries) [4,11,27], and the RES involved in the studies. It is worth noting that, for the type of batteries, additional information was provided in Table 2, such as reused (when studies analyzed reused batteries), comparisons (when studies compared more than one type of ESS), or hybrid technologies (when studies included other energy system integrated to the RES).

In addition, content analysis of the paper sample also enabled the identification of the economic indicators or criteria used in each study, as indicated by Table 2: net present value (NPV); net present cost (NPC), or life cycle cost analysis (LCCA); internal rate of return (IRR); payback (PB); discounted payback (DPB); equivalent annual cost (EAC); levelized costs of electricity (LCOE), and other indicators or methodologies (O). For the latter, cost or financial variables, cost-benefit ratio, or methodologies relevant to the feasibility theme were considered, such as Monte Carlo simulation (MCS) and real options (RO) theory.

Table 2 shows the indicators and the approaches used as decision-making criteria in studies of financial or economic viability. Some studies stood out for carrying out a comprehensive study of financial feasibility using different approaches to obtain a direct answer that influenced the decision of investors. Others addressed technical characteristics or were focused on other factors (environmental, technical, scale decision, technology, etc.) in which one of the considered variables was an economic variable or a financial metric.

As shown in Table 2, NPV stood out as the most commonly used indicator within the analyzed literature, present in 42 of the studies, based on the concept of discounted cash flow (DCF). In addition, in the analyzed literature, it stood out for being one of the main economic indicators used to evaluate the performance of a system [66] and for including the time factor with the interest rate [27]. The NPV allows one to quantify the profits $[36,59]$ being calculated as the difference between the present value of the benefits obtained and the costs incurred in an investment [27], whose simplified model can be represented by Equation (1) $[23,66,72,82]$ :

$$
N P V=-I+\sum_{j=1}^{n} \frac{C F_{j}}{(1+k)^{j}}
$$

where $I$ indicates the investment; $C F_{j}$ represents the cash flow in period $j$; and $k$ indicates the discount rate. In this case, an investment is considered economically viable when NPV $>0$ [62].

Explicitly present in 11 of the analyzed articles, the life cycle cost analysis (LCCA), also known as net present cost (NPC), is a criterion analogous to net present value (NPV), ideal for assessing the total cost of ownership of machines and equipment [78]. The NPC 
of a system is defined as the present value of all capital and recurring costs that the system incurs throughout its lifetime $[3,28,101]$. In its calculation are considered initial costs, operation and maintenance (O\&M) costs, replacement costs, residual values related to the entire life cycle, and other specific costs that can be considered (for example, fuel costs, emission penalties, costs of purchasing energy from the grid) $[23,37,77,78]$. Finally, in a simplified manner, the NPC or the LCCA can be represented by Equation $(2)[3,28,101]$ :

$$
\begin{gathered}
N P C=C_{0}+C_{R}+C_{O \& M}-C_{R V} \\
=C_{0}+\sum_{j=1}^{n} \frac{C_{R_{j}}}{(1+k)^{j}}+\sum_{j=1}^{n} \frac{C_{O \& M_{j}}}{(1+k)^{j}}-\frac{C_{R V n}}{(1+k)^{n}}
\end{gathered}
$$

where $C_{0}$ indicates the component initial cost; $C_{R_{j}}$ represents the regular component replacement cost in period $j ; C_{O \& M_{j}}$ represents the O\&M costs in period $j ; C_{R V_{n}}$ represents the residual value at the end of lifetime; and $k$ indicates the discount rate.

Being used in 14 of the analyzed studies, IRR is a criterion used in feasibility studies that identifies the interest rate that makes the NPV of all project cash flows equal to zero $[20,31,95]$. An investment is considered economically viable when the corresponding IRR value is above an acceptance limit, which can be defined according to market conditions [62]. Therefore, the IRR criterion can be represented by Equation (3) [20,31,43,62]:

$$
0=-I+\sum_{j=1}^{n} \frac{C F_{j}}{\left(1+k_{I R R}\right)^{j}}
$$

where $I$ indicates the investment; $C F_{j}$ represents the cash flow in period $j$; and $k_{I R R}$ is the internal rate of return.

The PB is a simple approach presented in 23 of the analyzed studies used to indicate the time required after an investment to recover the initial costs. The project is considered economically unviable when the $\mathrm{PB}$ is longer than the useful lifetime of the evaluated systems $[39,79]$. The PB is used as an alternative to NPV, although it does not consider the value of money over time. In other words, it is a simpler criterion with a greater potential for imprecision [52]. It is interesting to highlight that this indicator was used in a way that was complementary to others considered more accurate, or else, it was adopted as a financial indicator in the optimization of more comprehensive mathematical models, which justifies its relatively high occurrence.

Then, presented in ten of the analyzed studies, the DPB appeared as an alternative to correct such inaccuracy, being used to identify the time required in years to reach the breakeven point [52]. Such an indicator is represented in a complementary form by Equations (4) and (5) [27,79]:

$$
\begin{gathered}
D C F=\frac{C F_{j}}{(1+k)^{j}} \\
D P B=L+\frac{C}{A}
\end{gathered}
$$

where $C F_{j}$ is the cash flow in period $j$, and $k$ indicates the discount rate. Moreover, $L$ is the last period with a negative discounted cumulative cash flow; $C$ is the absolute value of discounted cumulative cash flow at the end of the period $L$; and $A$ is the discounted cash flow during the period after $L$.

The present literature review shows that different parameters are considered to assess the economic benefits of ESS. In the economic evaluation of such systems, the component costs were calculated annually, using the EAC criterion, presented in 17 studies of the sample. This criterion consisted of annualizing the NPC and obtaining a uniform series of annual values, as can be represented by Equation (6) $[25,33,76,100]$ :

$$
E A C=N P C \frac{(1+k)^{n} k}{(1+k)^{n}-1}
$$


where NPC is represented by Equation (2); $n$ is the final period of the analysis horizon; and $k$ is the discount rate.

It was observed that the optimization conditions of some models proposed in the studies required an annualized cost value, which may have motivated the use of the EAC or similar approaches to annualize the results.

The LCOE was proposed as a mean of comparing electricity costs from renewable sources and conventional sources [70]. Currently, it is widely used as an index of the economic performance of ESS $[38,39,93]$, since it can be easily calculated to determine the average price of electricity with and without the use of storages [39].

Used in 24 studies, in general terms, the LCOE is calculated as the ratio between all the discounted costs over the useful lifetime of a system divided by the discounted sum of the actual energy values delivered [28,102], as presented by Equation $(7)[23,38,70,93]$.

$$
L C O E=\frac{\sum_{j=0}^{n} \frac{C_{j}}{(1+k)^{j}}}{\sum_{j=0}^{n} \frac{E_{T_{j}}}{(1+k)^{j}}}
$$

where $C_{j}$ is the total power generation costs for a given period $j ; n$ is the final period of the analysis horizon; $E_{T_{j}}$ is the annual total delivered energy in each period $j$; and $k$ is the discount rate.

It is interesting to note that some variants of the LCOE were identified, for example, specific variations for the analysis of ESS [31,43] or even hybrid ESS [70].

Furthermore, we sought to identify other relevant models that can be used in economic feasibility studies. Considering the wide occurrence of criteria based on the DCF method, it is important to note that the occurrence of the weighted average cost of capital (WACC) was observed in only four of the studies analyzed. Competing methods to DFC such as adjusted present value method and the cash flow to equity method were not identified. WACC is a method for calculating the interest rate (discount rate) $[45,52]$ and can be represented by Equation (8) [52]. It should be noted that most authors preferred to rely on other studies in the literature, technical reports from national and international agencies, or other publications (banks rates, risk-free rates, and others) to identify the ideal value of the discount rate to be applied in their studies.

$$
W A C C=k_{d} D(1-\tau)+k_{e} E
$$

where $k_{d}$ represents the cost of debt; $D$ is the weight of debt (\%); $K_{e}$ is the cost of equity; $E$ is weight of equity (\%); and $\tau$ is the income tax [109].

Finally, in Table 2, the column "Others" is presented, which specifies the studies where other financial and economic parameters or indexes were adopted. Usually, such indicators were used in a complementary manner to the traditional criteria or were used as variables in the different optimization models proposed. These included return on investment, energy return on investment, capex (capital expenditures), opex (operating expenditures), and cost indexes or cost-benefit ratios. Moreover, the articles that used MCS to assist in stochastic analyzes and those that used real options (OR) theory were highlighted.

\subsection{Predominant Cluster Framework}

To address RQ3 (what are the key paper clusters presented by the referred literature?), clustering techniques and content analysis were combined. Mapping and clustering techniques are often used in systematic reviews $[110,111]$. The purpose of using these techniques is to provide an overview of the structure of a network, answering questions such as "what are the main fields of investigation in a scientific domain?" or "how do these topics relate to each other?", among others. 
According to Waltman et al. [112], mapping and grouping techniques are used in combination in order to build a map in which it is possible to display a cluster of nodes on the map, highlighting the areas that correspond to the clusters.

In this article, it was decided to carry out a bibliographic coupling network to answer RQ3. In this type of analysis, the papers ' relationship was determined based on the degree to which they cited the same publications, that is, the more two researchers cited the same publications, the stronger the relationship between them was. Still, we opted for a fractional count, which meant that a publication in co-authorship was attributed fractionally to each of the co-authors, with the total weight of the publication being equal to one, that is, each publication had the same general weight. For more information about the method and its mathematical formulation, the study by Perianes-Rodriguez et al. [110] is recommended.

Thus, based on the criteria presented and using the software VOSViewer, Figure 10 was developed. This Figure presents in-depth content analysis of the paper samples with special attention to abstract, introduction, and conclusion sections to identify common research themes and interests that represent each paper cluster. Thus, as further discussed in the next subsections, three predominant clusters were identified:

i PV systems with battery storage for residential areas;

ii comparison between energy storage technologies;

iii power quality improvement.

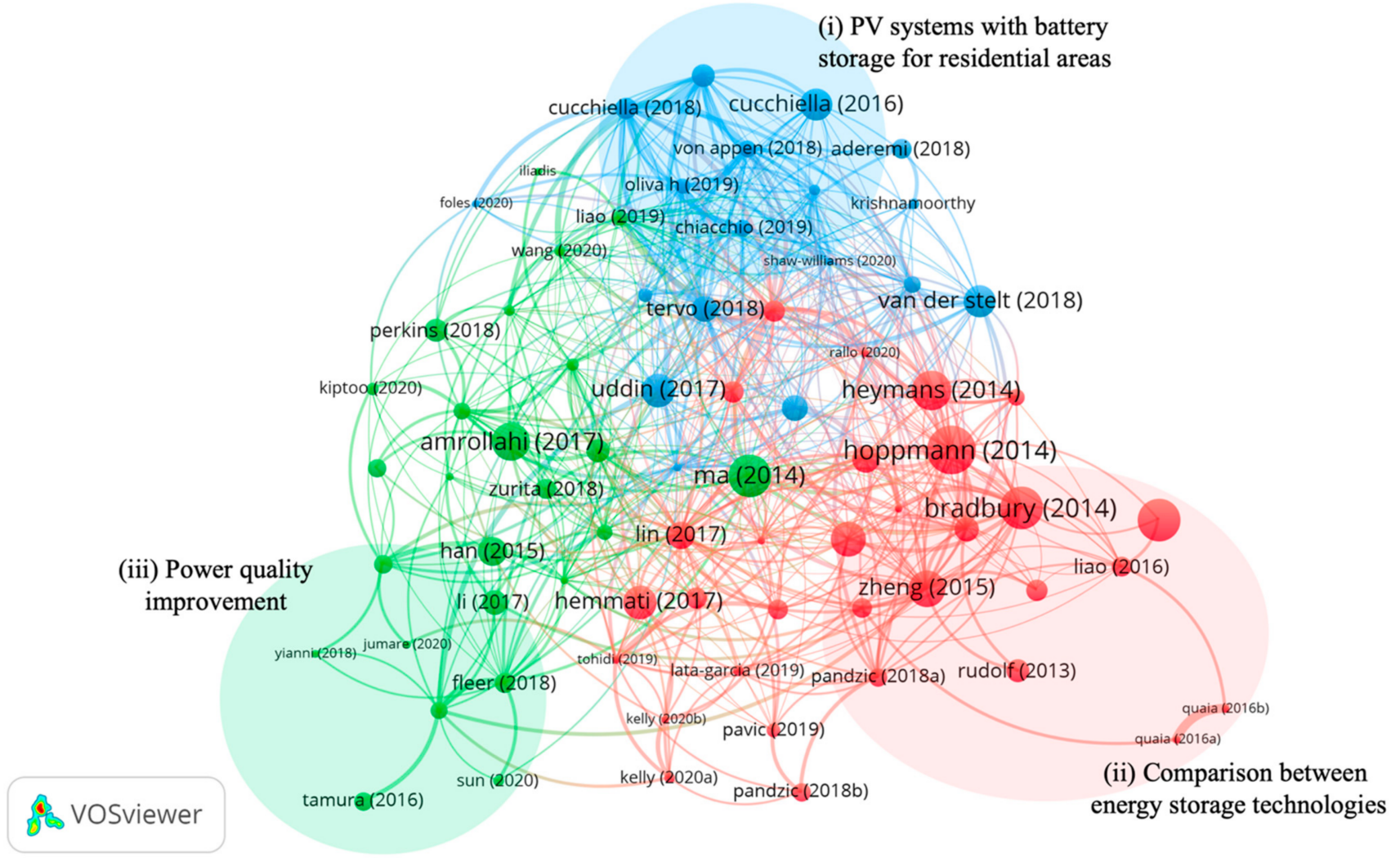

Figure 10. Predominant cluster framework based on the bibliographic coupling network.

\subsubsection{PV Systems with Battery Storage for Residential Areas}

According to Oliva et al. [41], decentralized small electricity generation systems from RES experienced remarkable growth in the last decade, arousing greater interest from researchers [36,68]. The significant drop in PV system prices [41] combined with strong government support [1] significantly contributed to the development of the distributed PV systems. 
The sun is the most abundant energy source on the planet, being non-pollutant and cost-free [1]. Electricity from the sun is produced after converting solar radiation into energy, which is why it has an intermittent nature. The need for ESS arises from the intermittent nature of solar energy sources [82]. Small-scale distributed storage in residences could facilitate the integration of intermittent RES $[17,65,82,95,113]$.

According to Uddin et al. [19], BESS are generally considered an effective means for reducing the energy mismatch between PV supply and residential demand. The use of these systems is stimulated by the great reduction in the cost of modern batteries [114,115].

Other aspects related to the stimulus for the implementation of distributed PV generation refer to public policies. In this context, net metering is the most widely implemented policy for distributed PV generation [41]. Another important mechanism for this purpose is the feed-in tariff [46]. Since the credits generated by saving electricity can be considered as revenue from electricity micro-generation, it is relevant to apply a robust tool, such as $\mathrm{NPV}$, to analyze the economic viability of this type of project.

Among the articles analyzed in the SLR for the composition of the "PV systems with battery storage for residential areas" cluster, the following articles can be highlighted in the discussion on the use of BESS in association with distributed PV generation for residential scale.

Cuchiella et al. $[30,32,36]$ evaluated the profitability of integrated battery residential PV systems in Italy. For that, in the three studies, they used electrochemical storage systems, considering lead-acid batteries. The decision criterion adopted was the NPV, being considered the most robust of the criteria. Cuchiella et al. [30] evaluated the profitability of PV systems without subsidies and the ESS in a market recognized as mature. Searching for the break-even point that makes systems economically viable, they concluded that storages are really indispensable when the relationship between supply and demand allows inducing a significant increase in energy self-consumption. Cuchiella et al. [32] analyzed the investment in the ESS considering incentives for tax deductions and regional subsidies. The study adopted several combinations between the variables and confirmed that viability can be achieved when there are incentives. Finally, in Cuchiella et al. [36], the authors evaluated different scenarios related to the plant of a residential building and combined different critical variables, such as insolation level, energy sales prices, energy purchase prices, investments, deductions, battery size, useful lifetime, and value of investment in ESS. In addition, they pointed out that the profitability of PV systems integrated with BESS is lower than the NPV obtained by the same system without ESS.

Oliva et al. [41] analyzed residential PV generation in Australia combined with energy efficiency technologies and BESS. The results obtained show that the use of energy efficiency technologies can reduce the PV system's revenue and that the addition of BESS associated with this system can increase the PV system's revenue. They showed that the costs for a residential application were still high when the research was carried out. Finally, they claimed that there seems to be competition between energy efficiency technologies and ESS in the search for bill savings during peak hours.

The study presented by Gagliano et al. [52] aimed at evaluating PV systems associated with ESS dedicated to residential consumers and small businesses in Italy. Different combinations were evaluated considering plant sizes, domestic consumption, and energy storage capacity. The authors sought to identify the best combination that allows achieving a good relationship between self-sufficiency and less exchange with the grid. Still, they analyzed the economic viability of the ESS. The results indicated the economic viability for the Italian market. The possibility of increasing domestic electrical self-sufficiency through these PV systems connected to ESS represents a great opportunity for the entire electricity system.

Tervo et al. [38] performed a modeling involving the energy saving in a residential PV system with Li-ion batteries in the USA. They also evaluated the performance of this system over its useful lifetime. The authors concluded that, with the correct sizing, financing, and incentives currently available, the combined system can be more financially attractive than the PV system without BESS. 
Therefore, it was possible to have a greater understanding about the cluster (i) formed using the concept of bibliographic coupling network. It was observed that, in the articles concentrated at the apex of the triangle formed by the clusters (see Figure 10), the authors focused on research especially about the economic feasibility of PV energy on a residential scale. Moving slightly away from this apex, it was possible to find articles such as the one by Aderemi et al. [28] that analyzed the viability of PV energy on a non-domestic scale (isolated) or Krishnamoorthy et al. [77], in which it is faced with an increase in scale (region/community) and hybrid systems involving RES. When moving towards the cluster (ii), it was possible to find articles that developed economic and financial studies that can help in the decision-making processes between different energy storage technologies (e.g., between electrochemical batteries), as were the cases of Martinez-Bolanos et al. [59] and Barcellona et al. [34], who dealt with the PV source on a residential and a commercial and industrial scale, respectively, but performed the comparison between different technologies. On the other hand, when moving towards the cluster (iii), it was possible to identify articles such as Dumont et al. [49] and Uddin et al. [19], which, despite the studies being carried out on PV energy at the residential scale, involved issues of energy management or reliability (e.g., load shifting and peak shaving).

\subsubsection{Comparison between Energy Storage Technologies}

According to Das et al. [4], electricity grids can use numerous energy storage technologies, which are categorized as follows: electrical, mechanical, electrochemical, thermochemical, chemical, and thermal. In this study, only the electrochemical energy storage technology was considered.

Some review articles referring to the other types of energy storage for grid applications can be found in [116-123]. In particular, specific reviews on energy storage technologies are provided concerning the technical characteristics of different ESS [116,117] and including details on the enabling power electronics [118], or on properties and functionalities of grid-scale applications [119], or with specific focus on thermal energy storage [120]. Wide reviews are available for addressing many aspects of energy storage systems [121], also aimed at providing a structured literature review on BESS for RES integration [122]. Insights on cost analysis including life cycle costs of EES systems are presented in [123]. However, none of these articles include a systematic literature review dedicated to the economic analysis of investments in BESS driven by structured research questions such as the one presented in this article.

Electrochemical energy storage is a generic name for batteries. Batteries are electrochemical devices with the ability to readily convert the stored energy into electricity. Batteries can be primary or secondary, i.e., non-rechargeable or rechargeable, respectively. These devices can be solid-state batteries or flow batteries [77]. Since only secondary batteries are useful for large-scale energy storage, we can define four batteries groups of interest $[4,11,27]$ : lead-acid, NaS, Li-ion, and flow battery.

Depending on the energy storage and delivery characteristics, a battery can play many roles in the grid [10]. Batteries can have different characteristics, such as [4,27]: cost, charge time, discharge time, lifetime in years, cycling capability, charging and discharging efficiency, response time, capacity, and environmental impact. Due to these different characteristics, the economic feasibility analysis of projects involving BESS becomes a non-trivial task.

Generally, the articles in the literature which are dedicated to comparing energy storage technologies compare either different types of storage technology (e.g., [54,71,86,87] and others) or different types of batteries (e.g., [20,21,23,50,64] and others), as seen in detail in Table 2. Key contributions of the analyzed papers are presented in the next paragraphs.

Kaldellis et al. [21] presented a technical-economic comparison of various RES configurations associated with ESS in order to serve as a backup of existing thermal units in Greek islands. For that, an integrated methodology of techno-economical evaluation was conducted. The authors identified that $\mathrm{NaS}$ batteries are more suitable for small islands, 
while lead-acid batteries and pumped hydro storage (alternative to batteries) can be seen as a suitable solution for large islands. Finally, fuel cells and flow batteries can represent promising future solutions, depending on the cost reduction of such technologies.

Quaia [86,87] presented his study divided into two parts. In the first article, the author carried out a preliminary comparative analysis [86]. In the second article, the author carried out an economic assessment of different ESS [87]. For this, the author used the criteria of payback and NPV. The results indicated that NaS batteries have the lowest capex and, consequently, the best performance in the economic evaluation. Next in the classification are lead-acid batteries. Finally, Li-ion batteries were identified as not economically competitive.

Bradbury et al. [20] presented a linear optimization model with the purpose of finding the power of storage systems and the energy capacities that maximize the IRR when used to arbitrate electricity prices. The study was conducted in the USA and considered 14 different ESS technologies (electrochemical batteries and other technologies). The results proved that the profit maximization of a BESS is mainly determined by its technical characteristics (e.g., round trip charge, discharge efficiency, and self-discharge) and not by volatility of market price.

Ren et al. [64] proposed an analysis of the technical feasibility of energy storage technologies for RES (hybrid PV-wind). In addition, different ways of combining energy storage technologies (electrochemical batteries and other technologies) were proposed. Then, an economic analysis of hybrid energy storage technologies was conducted. The results of the simulations indicated that it is possible for a hybrid storage system to be applied in an autonomous renewable energy generation system.

Dufo-Lopez and Bernal-Agustin [23] proposed a method to evaluate technical and economic performance of a system connected to the grid with storage under an electricity tariff by time-of-use in Spain. The proposed system should be considered valid for any type of storage and scale (residential, commercial, and industrial), but it was used only for lead-acid or Li-ion batteries. For this, the authors used criteria such as NPV, NPC/LCCA, and LCOE. The results indicated that the most critical parameters are the investment in the battery bank and the number of cycles to failure.

Using the concept of bibliographic coupling network, it was observed that cluster (ii) concentrated studies that carried out comparisons between different technologies (electrochemical batteries, other technologies, or even hybrid battery systems). Moving towards cluster (i), it was possible to find studies such as Heymans et al. [24], Rallo et al. [60], and Bai et al. [66], which analyzed the feasibility in the reuse of batteries (second life used) as ESS in residential, commercial and industrial, and region/community scales, respectively. Two of them are associated with PV generation. Moving towards cluster (iii), it was possible to find studies such as Hemmati [33], Lin and $\mathrm{Wu}$ [90], and Tohidi and Gibescu [51], which not only compared technologies but also sought to encompass issues of energy management and reliability.

\subsubsection{Power Quality Improvement}

RES, mainly wind and PV energy, are more subject to randomness and variations than traditional power plants supplied by non-renewable energy sources. Because of these aspects, it becomes rather hard to estimate the power generation profile with good accuracy. In fact, by converting wind and solar energy into electricity, randomness and variability in the environment strongly impact on randomness and variability of the power produced, also affecting power quality $[17,39,124]$.

According to Rodway et al. [124], fluctuations in energy sources, especially renewable ones, are known to have a significant impact on energy systems. This fact may represent an issue to be solved when considering the use of RES associated with high variability and low predictability, which is the case of PV and wind energy $[52,67,100]$. Moreover, the non-constant power flow can cause major problems in power quality, including harmonics, imbalances, and distortions. 
Therefore, a great challenge for the system operators is to stabilize the electricity grid, especially when considering the supply of the network sustained by intermittent RES [91]. To fulfill this function, ESS have been considered [51,53,78,89,125].

According to Das et al. [4], the ESS can be applied in the grid to offer technical, economic and environmental support, providing power quality improvement, mitigation of voltage deviation, frequency regulation, load shifting, load levelling and peak shaving, facilitation of RES integration, network expansion and overall cost reduction, operating reserves, and greenhouse gases emissions reduction.

Considering the improvements in reliability and efficiency of ESS associated with the acceptable cost-benefit ratio, there is an increasing participation in the electricity power system [126]. In addition, ESS are being used to perform new functions [127,128], such as improving energy management and protection [129]. Thus, it is possible to integrate the non-dispatchable renewable sources [128].

Power quality is a broad subject, which can be affected by the most diverse factors, causing disturbances in the energy system [130]. Therefore, power quality must be treated as an essential measure and focused on the customer being directly affected by transmission and distribution operations. In this way, power quality becomes a key issue for RES [131].

The simplest definition of power quality can be given as the occurrence of deviations in current, voltage, and frequency from their standard values in normal operation, which can result in equipment operation failures [124,132]. In addition, it can be attributed to several disturbances such as harmonics, multiple notches, interruptions, impulsive and oscillatory transients, swell, voltage flicker, and sag, and its effects are considered relatively expensive [52,102,124,133].

Finally, in large-scale plants, ESS can be considered extremely relevant, since its energy reserve can assist in meeting current and future grid requirements. Besides that, considering the cost-benefits relations [107], its uses can make projects involving RES more attractive to investors [128]. Such facts can allow the increase of the participation of the RES, avoiding undesirable risks of power quality.

Among the articles analyzed in the SLR for the composition of the "power quality improvement" cluster, some articles could be highlighted to exemplify the use of BESS in applications for maintaining power quality.

Tamura [88] studied the application of a hybrid ESS using two different kinds of battery to frequency control as well as peak shift and its economic analysis. The author proposed a method of quantitatively evaluating the costs related to hybrid BESS. His results showed that the hybrid battery system offers higher economic efficiency for frequency control than the single-type battery system and that Li-ion batteries are more cost-efficient than advanced lead-acid batteries. Regarding the use of a hybrid battery system for peak shifting, the resulting cost advantage was moderate.

Yianni et al. [95] stated that BESS can provide several services to the power grid with various financial potentials. The authors analyzed the economic viability of BESS providing primary frequency regulation services in European markets. For all examined markets, i.e., mainland UK (Great Britain) and Central Europe, a positive NPV and high IRR were obtained, denoting a profitable and attractive investment, although risks related to regulations and uncertainties of each country existed.

Fleer et al. [91] analyzed, in the German context, the profitability of an investment in a BESS given a scenario of decreasing prices both for the primary control reserve market and for the prices of cells and battery systems. The authors analyzed different bidding strategies for primary control reserve auctions and their impact on NPV. The primary control reserve and BESS prices decisively affected the viability of the investment. Due to the uncertainties inherent to these factors, the authors concluded that this type of investment has a high risk.

Engels et al. [98] optimized a BESS for frequency control services in the German market. The authors considered minimum degradation and electricity costs over the investment lifetime while ensuring the delivery of frequency control services compliant with regulatory requirements. They found that a BESS rated at 1.6 MW/1.6 MWh provides 
the highest NPV. In addition, this configuration is profitable if the costs remain low and if the frequency control prices do not drop too much.

Sun et al. [104] argued that the need for power grid frequency regulation is increasing due to the rapid growth of power generation from RES. In this context, the BESS could be used to correct the power system's unbalance of instantaneous power. Thus, the cost-benefit model of the BESS participating in automatic generation control ancillary service was established. The authors concluded that the control strategies and the energy configuration method can improve the performance and the economic return of the system.

It was possible to observe that, in cluster (iii), elaborated from the use of coincidental references, the authors focused on issues involving energy quality and reliability. When moving towards cluster (i), the studies usually had a reduction in the generation scale analyzed until they approached the residential scale, usually testing the viability of PV sources, as was the case with studies such as Wang et al. [46] and Kiptoo et al. [76]. When moving towards cluster (ii), the articles continued to deal with issues involving energy quality and reliability but also testing and comparing the different electrochemical technologies or other types of ESS, as seen in Ma et al. [3] and Mostafa et al. [102].

\section{Research Agenda}

To answer the RQ4 (what are the key research opportunities for the literature regarding economic analysis of BESS?), we used indications from answering the previous research questions and gaps recognized by the paper sample (see Figure 11).

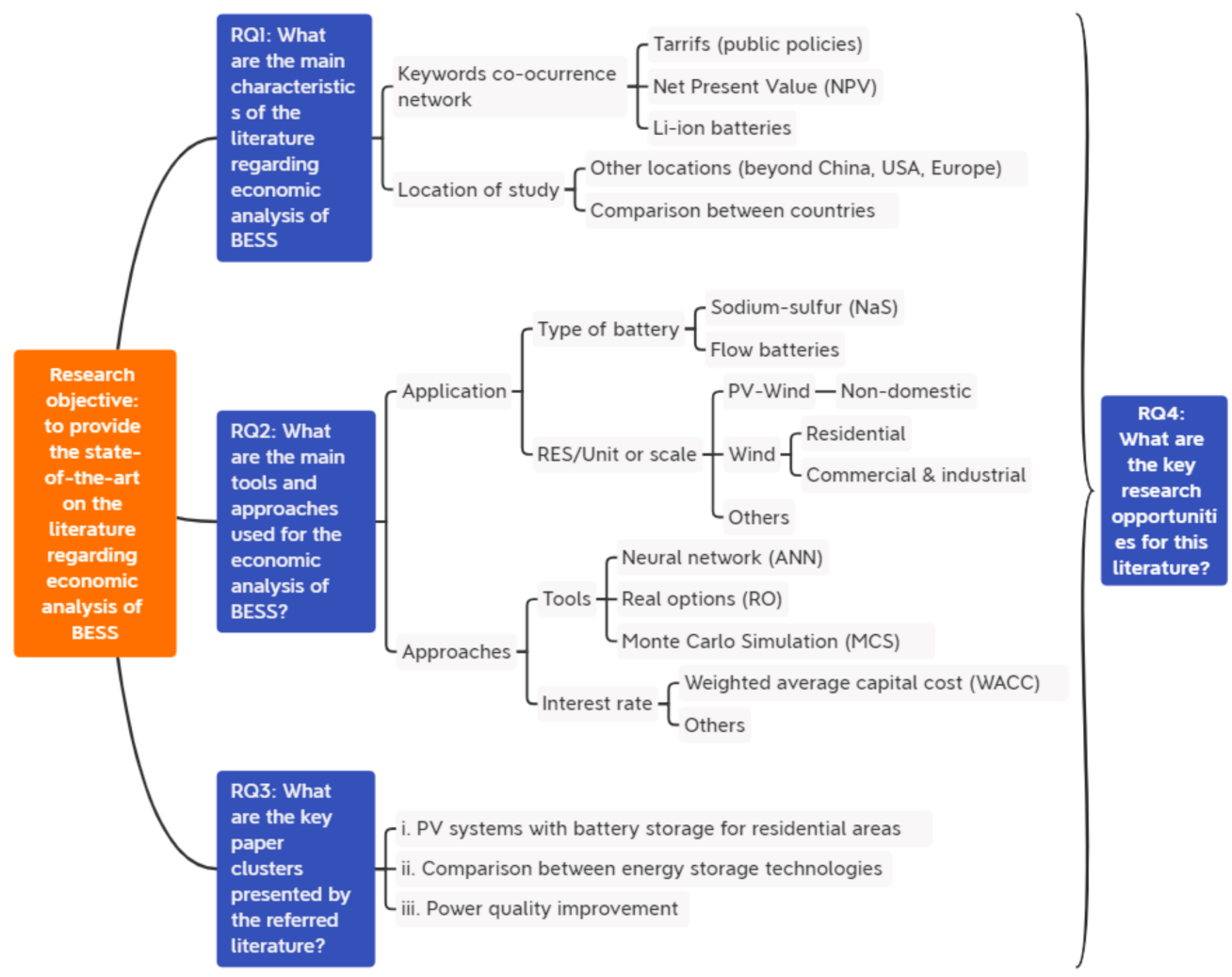

Figure 11. Research agenda.

During the sample characterization (RQ1), recent research interests were identified by the keyword network (Figure 5). It highlighted growing researchers' interest on the Li-ion type of battery. Moreover, the keyword network (Figure 5) showed that NPV appears as a recent research interest, which is a more adequate financial decision criterion that is able to evaluate costs and revenues over time in comparison with other economic indicators that do not consider DCF approach. Another recent research interest includes debates on tariffs, as they have direct influence on economic viability of energy systems associated 
with BESS. Thus, associated public policies are key in promoting investments in this market for cost reduction and increase renewable energy participation in the country's energy matrix. The present proposed research agenda suggests that this and other context-specific characteristics can be opportunity for future studies, especially exploring other locations beyond China, the USA, and Europe. Figure 7 shows the concentration of studies in these areas, indicating opportunities for exploring other settings as well as comparisons between different locations.

Retrieving Table 2 regarding tools and approaches for economic analysis of BESS (RQ2), several other research opportunities emerged. Considering the different applications of the economic analysis of systems including BESS, there is a gap in economic feasibility studies that deal with wind power generation associated with BESS on residential or commercial and industrial scales. Only the study by Hemmati [33] was identified as an exclusive study of this source of energy, which provides space for further studies (especially with wind turbines with size below $1 \mathrm{MW}$ ). In addition, feasibility studies applied to the combined use of BESS and RES, other than solar PV, can be explored. It was observed that only Aderemi et al. [28] developed studies on a non-domestic unit (e.g., mobile cellular base station or other transmission service base station). Consequently, non-domestic applications need to be better evaluated. Regarding the type of battery, it was possible to identify that the studies mainly focused on Li-ion and lead-acid batteries, with few studies being carried out exclusively on $\mathrm{NaS}[55,82,101]$ and flow batteries $[51,64,65,99]$ on any scale. However, we noted that many studies compared different energy storage technologies (cluster (ii)).

In the analysis stage of the economic indicators or criteria used by the feasibility studies in BESS (still regarding RQ2, Table 2), it was identified that only one [73] took advantage of the artificial neural network tool, in this specific case, as a machine learning tool. Further studies using artificial neural network can contribute to predicting feasibility criteria using BESS parameters as input variables for the model. The RO theory is adopted as a refined tool to support decision making and can capture the managerial flexibility available in projects and the ideal scenarios in response to changes caused by uncertainties [134]. Besides, RO can be considered the most holistic approach that allows the assessment of the financial viability of BESS [75]. Despite these advantages, only two studies [75,84] of the paper sample adopted this tool, indicating opportunity for further studies. Another tool that can be deeper explored by feasibility studies in BESS is MCS. This provides the advantage of allowing the use of probability distributions of different stochastic variables (whether technical or financial) to perform multiple iterations to provide the impact of the input variables uncertainty on the final results [135]. Thus, it can be applied directly in financial decision-making criteria or indicators. Another relevant aspect to be considered by future studies performing economic analysis of BESS is the well-adjusted assumption for discount rates (interest rates) or capital cost. This is especially relevant in the case of RES, in which the cost of capital differs widely between countries and technologies involved [136]. Table 2 shows that only few studies [45,52,87] presented the calculations for obtaining the discount rate. Steffen [136] presented a discussion of methods for estimating WACC, cost of debt, cost of equity, and debt share. Aspects of this study can be further explored in BESS feasibility studies.

The delimitation of the three research clusters (RQ3, Figure 10) enabled the identification of different interests of study. Open questions for debate are especially the economic viability of PV systems with BESS in residential areas (cluster (i)), the technical and the economic feasibility of different ESS technologies (cluster (ii)), and the factors that influence the application of BESS for power quality and reliability improvement (cluster (iii)). Figure 12 shows the evolution of the number of publications over time for each of the predominant clusters. Since 2017, there is a growing interest of studies belonging to cluster (iii), indicating a trend of growing research field to be explored. Due to recent advances in relation to regulatory aspects in several countries around the world, the issue of remuneration for power quality improvement services provided to the grid is a subject 
of growing interest. In this way, BESS can become its own market niche, and players can be remunerated for the availability of storage provided to the grid.

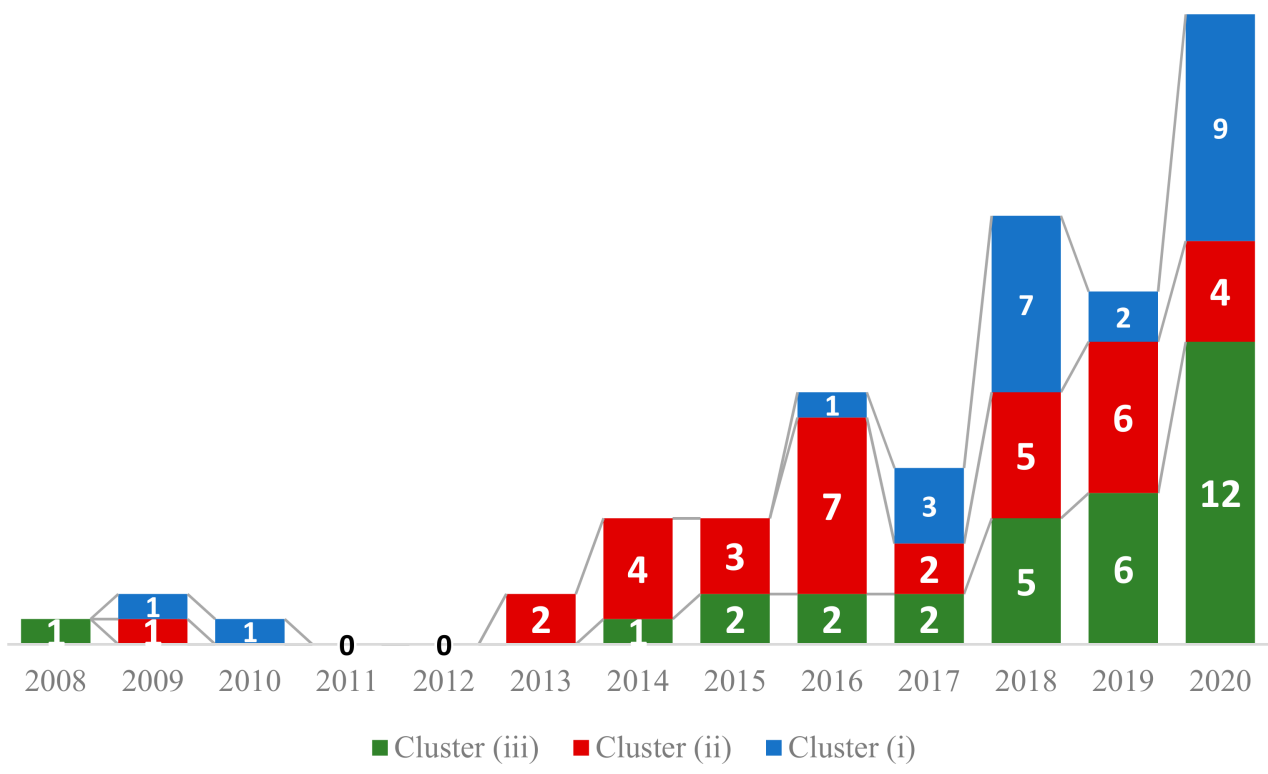

Figure 12. Evolution of the number of publications by identified predominant clusters.

\section{Conclusions}

This article proposed a review of the state-of-the-art on the literature regarding economic analysis of BESS, considering four research questions (RQ1: what are the main characteristics of the literature regarding economic analysis of BESS? RQ2: what are the main tools and methods used for the economic analysis of BESS? RQ3: what are the key paper clusters presented by the referred literature? RQ4: what are the key research opportunities for this literature?). For this, an SRL was conducted following the guidelines from the literature [12,15]. A sample of 92 articles extracted from the Web of Science and Scopus was analyzed using bibliometric quantitative techniques associated with qualitative content analysis.

The novelty of the present research is evident, as it was not found in previous systematic literature reviews regarding studies comprising economic analysis of energy systems integrated with BESS. Thus, this research presented an in-depth critical analysis of the state-of-the art of the referred literature towards proposing research agendas for future studies. Several contributions can be derived from the present paper. First, it made evident the growing interest of batteries as ESS to provide techno-economic viability of renewable energy systems (Figure 3), and other general characteristics of the literature on economic analysis of BESS were exposed. Second, the paper provided a comprehensive overview of key methodological possibilities for researchers interested in economic analysis of BESS. This contribution is evident by looking at Table 2, which summarizes the combinations between different application settings (unit of analysis, type of grid, type of battery, RES) and economic indicators/criteria present in the literature. Third, another contribution is the indication on the need to use adequate economic indicators for investment decisions.

The paper sample comprised studies providing both technical and economic viability analysis. However, when deploying the economic viability decision criteria, some of them used only a cost or PB indicator without applying the proper discount rate recommended by DCF. For a good execution of the feasibility analysis using the NPV criterion, it is essential to correctly estimate the discount rate. For the finance literature, the use of models such as the weighted average cost of capital (WACC) is considered as suitable for estimating this interest rate. In this sample, only two of the articles used a methodology to calculate the discount rate. The article highlights the opportunities for feasibility studies, as the use of such criteria often does not seem to be as obvious, as does the NPV. 
PV and LCOE were introduced by other sample papers, providing a more consistent economic analysis. Yet, the proposed research agenda (Figure 11) indicates opportunities for more refined approaches to assess economic viability of BESS, such as artificial neural networks, RO, MCS, and the use of other economic indicators from the DCF background such as WACC. Fourth, our research also contributes to the literature by identifying key research topics of the analyzed literature (Figure 10). Cluster (i) concentrated discussions of economic feasibility of PV power generation using BESS on a residential scale, also dealing with issues of fiscal incentives and public policies aimed at this type of generation. Cluster (ii) concentrated discussions on the comparison of BESS technologies and their different characteristics. Due to these characteristics, the economic feasibility analysis of projects involving BESS becomes a non-trivial task. Finally, cluster (iii) included studies involving grid quality and reliability services, such as mitigation of voltage deviation, frequency regulation, load shifting, load leveling and peak shaving, facilitation of RES integration, network expansion, and operating reserves. The last key contribution of the present paper is the proposed research agenda (Section 4), indicating relevant opportunities for future studies on this area of knowledge.

Research limitations are connected to the methodological choices associated with the SLR. First, the limitation to only two databases for paper extraction was mitigated by the choice of the databases among the largest for academic publications (Web of Science and Scopus). Second, the search strings selected could potentially exclude relevant publication on the analyzed literature. For this, several trial-and-error attempts of search strings combinations were performed. Besides, references most cited by the paper sample were analyzed to verify whether they were relevant enough to be in the paper sample. Final search strings were chosen when these relevant publications were considered by the paper sample. Third, the limitation of evaluating inclusion and exclusion criteria of each paper to form the final sample was mitigated by the refinement of the sample by three researchers rather than only one.

Author Contributions: Conceptualization, G.C., P.R.J., L.C.S.R. and A.M.; methodology, L.C.S.R., S.N.M. and P.R.J.; software, P.R.J., S.N.M. and I.B.; validation, L.C.S.R., P.R.J. and K.J.; formal analysis, P.R.J., L.C.S.R., S.N.M. and I.B.; investigation, P.R.J. and L.C.S.R.; resources, L.C.S.R., I.B., S.N.M. and P.R.J.; data curation, S.N.M., I.B. and P.R.J.; writing—original draft preparation, P.R.J., L.C.S.R., I.B. and S.N.M.; writing-review and editing, S.N.M., K.J., G.C. and A.M.; visualization, P.R.J. and L.C.S.R.; supervision, G.C. and P.R.J.; project administration, G.C., P.R.J., L.C.S.R. and A.M.; funding acquisition, G.C. and A.M. All authors have read and agreed to the published version of the manuscript.

Funding: This research received no external funding.

Institutional Review Board Statement: Not applicable.

Informed Consent Statement: Not applicable.

Data Availability Statement: Not applicable.

Acknowledgments: The authors P.R.J., L.C.S.R., S.N.M., and I.B. would like to thank the Brazilian National Council for Scientific and Technological Development-CNPq Brazil (Processes 406769/20184, 308021/2019-3, 302751/2020-3), the National School of Public Administration-ENAP Brazil (Process 04600.003102/2020-21), and the Coordination for the Improvement of Higher Education Personnel-Capes Brazil (Process PVEX—88881.337019/2019-01). The author K.J. thanks the Czech Science Foundation-Czech Republic (grant number 19-26812X) for the financial support and research incentive.

Conflicts of Interest: The authors declare no conflict of interest. 


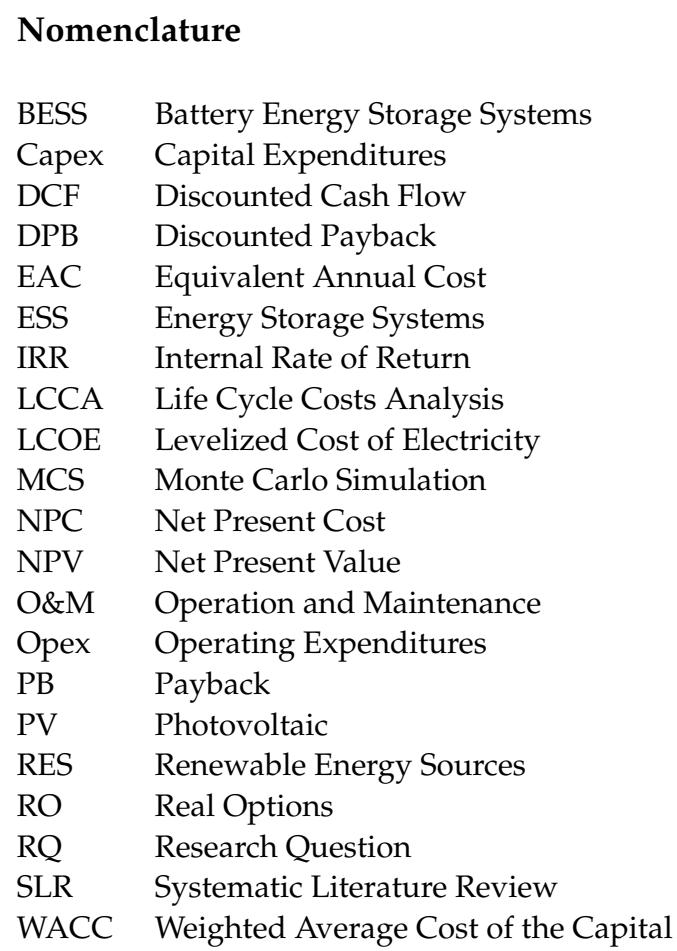

\section{References}

1. Rocha, L.C.S.; Aquila, G.; de Oliveira Pamplona, E.; de Paiva, A.P.; Chieregatti, B.G.; Lima, J.d.S.B. Photovoltaic electricity production in Brazil: A stochastic economic viability analysis for small systems in the face of net metering and tax incentives. J. Clean. Prod. 2017, 168, 1448-1462. [CrossRef]

2. Fagiani, R.; Barquín, J.; Hakvoort, R. Risk-based assessment of the cost-efficiency and the effectivity of renewable energy support schemes: Certificate markets versus feed-in tariffs. Energy Policy 2013, 55, 648-661. [CrossRef]

3. Ma, T.; Yang, H.; Lu, L. Feasibility study and economic analysis of pumped hydro storage and battery storage for a renewable energy powered island. Energy Convers. Manag. 2014, 79, 387-397. [CrossRef]

4. Das, C.K.; Bass, O.; Kothapalli, G.; Mahmoud, T.S.; Habibi, D. Overview of energy storage systems in distribution networks: Placement, sizing, operation, and power quality. Renew. Sustain. Energy Rev. 2018, 91, 1205-1230. [CrossRef]

5. Bakirtzis, E.A.; Simoglou, C.K.; Biskas, P.N.; Bakirtzis, A.G. Storage management by rolling stochastic unit commitment for high renewable energy penetration. Electr. Power Syst. Res. 2018, 158, 240-249. [CrossRef]

6. Mallapragada, D.S.; Sepulveda, N.A.; Jenkins, J.D. Long-run system value of battery energy storage in future grids with increasing wind and solar generation. Appl. Energy 2020, 275, 115390. [CrossRef]

7. Divya, K.C.; Østergaard, J. Battery energy storage technology for power systems-An overview. Electr. Power Syst. Res. 2009, 79, 511-520. [CrossRef]

8. Yekini Suberu, M.; Wazir Mustafa, M.; Bashir, N. Energy storage systems for renewable energy power sector integration and mitigation of intermittency. Renew. Sustain. Energy Rev. 2014, 35, 499-514. [CrossRef]

9. Evans, A.; Strezov, V.; Evans, T.J. Assessment of utility energy storage options for increased renewable energy penetration. Renew. Sustain. Energy Rev. 2012, 16, 4141-4147. [CrossRef]

10. Schoenung, S.M.; Eyer, J.M.; Iannucci, J.J.; Horgan, S.A. Energy storage for a competitive power market. Annu. Rev. Energy Environ. 1996, 21, 347-370. [CrossRef]

11. DeCarolis, J. Energy storage options for North Carolina. Policy Br. 2019, 1-2. Available online: https://energy.ncsu.edu/storage/ wp-content/uploads/sites/2/2019/02/NC-Storage-Study-FINAL.pdf (accessed on 11 December 2020).

12. Green, S. Systematic Reviews and Meta-Analysis. Singap. Med. J. 2005, 46, 270. [CrossRef]

13. Tranfield, D.; Denyer, D.; Smart, P. Towards a Methodology for Developing Evidence-Informed Management Knowledge by Means of Systematic Review. Br. J. Manag. 2003, 14, 207-222. [CrossRef]

14. Khan, K.S.; Kunz, R.; Kleijnen, J.; Antes, G. Five steps to conducting a systematic review. J. R. Soc. Med. 2003, 96, 118-121. [CrossRef] [PubMed]

15. Moher, D.; Liberati, A.; Tetzlaff, J.; Altman, D.G.; Antes, G.; Atkins, D.; Barbour, V.; Barrowman, N.; Berlin, J.A.; Clark, J.; et al Preferred reporting items for systematic reviews and meta-analyses: The PRISMA statement. PLoS Med. 2009, 6. [CrossRef] [PubMed]

16. Van Eck, N.J.; Waltman, L. Software survey: VOSviewer, a computer program for bibliometric mapping. Scientometrics 2010, 84, 523-538. [CrossRef] 
17. Hoppmann, J.; Volland, J.; Schmidt, T.S.; Hoffmann, V.H. The economic viability of battery storage for residential solar photovoltaic systems-A review and a simulation model. Renew. Sustain. Energy Rev. 2014, 39, 1101-1118. [CrossRef]

18. Diaf, S.; Belhamel, M.; Haddadi, M.; Louche, A. Technical and economic assessment of hybrid photovoltaic/wind system with battery storage in Corsica island. Energy Policy 2008, 36, 743-754. [CrossRef]

19. Uddin, K.; Gough, R.; Radcliffe, J.; Marco, J.; Jennings, P. Techno-economic analysis of the viability of residential photovoltaic systems using lithium-ion batteries for energy storage in the United Kingdom. Appl. Energy 2017, 206, 12-21. [CrossRef]

20. Bradbury, K.; Pratson, L.; Patiño-Echeverri, D. Economic viability of energy storage systems based on price arbitrage potential in real-time U.S. electricity markets. Appl. Energy 2014, 114, 512-519. [CrossRef]

21. Kaldellis, J.K.; Zafirakis, D.; Kavadias, K. Techno-economic comparison of energy storage systems for island autonomous electrical networks. Renew. Sustain. Energy Rev. 2009, 13, 378-392. [CrossRef]

22. Zheng, M.; Meinrenken, C.J.; Lackner, K.S. Smart households: Dispatch strategies and economic analysis of distributed energy storage for residential peak shaving. Appl. Energy 2015, 147, 246-257. [CrossRef]

23. Dufo-López, R.; Bernal-Agustín, J.L. Techno-economic analysis of grid-connected battery storage. Energy Convers. Manag. 2015, 91, 394-404. [CrossRef]

24. Heymans, C.; Walker, S.B.; Young, S.B.; Fowler, M. Economic analysis of second use electric vehicle batteries for residential energy storage and load-levelling. Energy Policy 2014, 71, 22-30. [CrossRef]

25. Amrollahi, M.H.; Bathaee, S.M.T. Techno-economic optimization of hybrid photovoltaic/wind generation together with energy storage system in a stand-alone micro-grid subjected to demand response. Appl. Energy 2017, 202, 66-77. [CrossRef]

26. Shihab, A.; Mandil, C.; Rostand, A.; Forrest, R. Introduction to Energy Poverty; A.T. Kearney Energy Transition Institute: Amsterdam, The Netherlands, 2018; Volume 95.

27. Fathima, H.; Palanisamy, K. Optimized Sizing, Selection, and Economic Analysis of Battery Energy Storage for Grid-Connected Wind-PV Hybrid System. Model. Simul. Eng. 2015, 2015. [CrossRef]

28. Aderemi, B.A.; Daniel Chowdhury, S.P.; Olwal, T.O.; Abu-Mahfouz, A.M. Techno-economic feasibility of hybrid solar photovoltaic and battery energy storage power system for a mobile cellular base station in Soshanguve, South Africa. Energies 2018, 11, 1572. [CrossRef]

29. Kantor, I.; Rowlands, I.H.; Parker, P.; Lazowski, B. Economic feasibility of residential electricity storage systems in Ontario, Canada considering two policy scenarios. Energy Build. 2015, 86, 222-232. [CrossRef]

30. Cucchiella, F.; D'Adamo, I.; Gastaldi, M. Photovoltaic energy systems with battery storage for residential areas: An economic analysis. J. Clean. Prod. 2016, 131, 460-474. [CrossRef]

31. Parra, D.; Walker, G.S.; Gillott, M. Are batteries the optimum PV-coupled energy storage for dwellings? Techno-economic comparison with hot water tanks in the UK. Energy Build. 2016, 116, 614-621. [CrossRef]

32. Cucchiella, F.; D'Adamo, I.; Gastaldi, M. The economic feasibility of residential energy storage combined with PV panels: The role of subsidies in Italy. Energies 2017, 10, 1434. [CrossRef]

33. Hemmati, R. Technical and economic analysis of home energy management system incorporating small-scale wind turbine and battery energy storage system. J. Clean. Prod. 2017, 159, 106-118. [CrossRef]

34. Barcellona, S.; Piegari, L.; Musolino, V.; Ballif, C. Economic viability for residential battery storage systems in grid-connected PV plants. IET Renew. Power Gener. 2018, 12, 135-142. [CrossRef]

35. Carriço, J.; Fernandes, J.; Fernandes, C.; Branco, P. Technical and economic assessment of a 450 W autonomous photovoltaic system with lithium iron phosphate battery storage. J. Sustain. Dev. Energy, Water Environ. Syst. 2018, 6, 129-149. [CrossRef]

36. Cucchiella, F.; D'Adamo, I.; Gastaldi, M.; Stornelli, V. Solar Photovoltaic Panels Combined with Energy Storage in a Residential Building: An Economic Analysis. Sustainability 2018, 10, 3117. [CrossRef]

37. Masebinu, S.O.; Akinlabi, E.T.; Muzenda, E.; Aboyade, A.O. Techno-economic analysis of grid-tied energy storage. Int. J. Environ. Sci. Technol. 2018, 15, 231-242. [CrossRef]

38. Tervo, E.; Agbim, K.; DeAngelis, F.; Hernandez, J.; Kim, H.K.; Odukomaiya, A. An economic analysis of residential photovoltaic systems with lithium ion battery storage in the United States. Renew. Sustain. Energy Rev. 2018, 94, 1057-1066. [CrossRef]

39. Van der Stelt, S.; AlSkaif, T.; van Sark, W. Techno-economic analysis of household and community energy storage for residential prosumers with smart appliances. Appl. Energy 2018, 209, 266-276. [CrossRef]

40. Von Appen, J.; Braun, M. Interdependencies between self-sufficiency preferences, techno-economic drivers for investment decisions and grid integration of residential PV storage systems. Appl. Energy 2018, 229, 1140-1151. [CrossRef]

41. Oliva, H.S.; Passey, R.; Abdullah, M.A. A semi-empirical financial assessment of combining residential photovoltaics, energy efficiency and battery storage systems. Renew. Sustain. Energy Rev. 2019, 105, 206-214. [CrossRef]

42. Dong, S.; Kremers, E.; Brucoli, M.; Rothman, R.; Brown, S. Techno-enviro-economic assessment of household and community energy storage in the UK. Energy Convers. Manag. 2020, 205. [CrossRef]

43. Foles, A.; Fialho, L.; Collares-Pereira, M. Techno-economic evaluation of the Portuguese PV and energy storage residential applications. Sustain. Energy Technol. Assess. 2020, 39, 100686. [CrossRef]

44. Nousdilis, A.I.; Kryonidis, G.C.; Kontis, E.O.; Barzegkar-Ntovom, G.A.; Panapakidis, I.P.; Christoforidis, G.C.; Papagiannis, G.K. Impact of policy incentives on the promotion of integrated PV and battery storage systems: A techno-economic assessment. IET Renew. Power Gener. 2020, 14, 1174-1183. [CrossRef] 
45. Shaw-Williams, D.; Susilawati, C.; Walker, G.; Varendorff, J. Towards net-zero energy neighbourhoods utilising high rates of residential photovoltaics with battery storage: A techno-economic analysis. Int. J. Sustain. Energy 2020, 39, 190-206. [CrossRef]

46. Wang, Y.; Das, R.; Putrus, G.; Kotter, R. Economic evaluation of photovoltaic and energy storage technologies for future domestic energy systems-A case study of the UK. Energy 2020, 203. [CrossRef]

47. Pereira, L.; Cavaleiro, J.; Barros, L. Economic assessment of solar-powered residential battery energy storage systems: The case of madeira island, portugal. Appl. Sci. 2020, 10, 7366. [CrossRef]

48. Deotti, L.; Guedes, W.; Dias, B.; Soares, T. Technical and Economic Analysis of Battery Storage for Residential Solar Photovoltaic Systems in the Brazilian Regulatory Context. Energies 2020, 13, 6517. [CrossRef]

49. Dumont, O.; Carmo, C.; Georges, E.; Quoilin, S.; Lemort, V. Economic assessment of electric energy storage for load shifting in positive energy building. Int. J. Energy Environ. Eng. 2017, 8, 25-35. [CrossRef]

50. Al-Foraih, R.; Sreekanth, K.J.; Al-Mulla, A. A techno-economic analysis of the integration of energy storage technologies in electric power systems. J. Renew. Sustain. Energy 2018, 10, 054102. [CrossRef]

51. Tohidi, Y.; Gibescu, M. Stochastic optimisation for investment analysis of flow battery storage systems. IET Renew. Power Gener. 2019, 13, 555-562. [CrossRef]

52. Gagliano, A.; Nocera, F.; Tina, G. Performances and economic analysis of small photovoltaic-electricity energy storage system for residential applications. Energy Environ. 2020, 31, 155-175. [CrossRef]

53. Yan, X.; Zhang, X.; Chen, H.; Xu, Y.; Tan, C. Techno-economic and social analysis of energy storage for commercial buildings. Energy Convers. Manag. 2014, 78, 125-136. [CrossRef]

54. Barberis, S.; Rivarolo, M.; Traverso, A.; Massardo, A.F. Thermo-economic analysis of the energy storage role in a real polygenerative district. J. Energy Storage 2016, 5, 187-202. [CrossRef]

55. Liao, Q.; Sun, B.; Liu, Y.; Sun, J.; Zhou, G. A techno-economic analysis on NaS battery energy storage system supporting peak shaving. Int. J. Energy Res. 2016, 40, 241-247. [CrossRef]

56. Pandžić, H. Optimal battery energy storage investment in buildings. Energy Build. 2018, 175, 189-198. [CrossRef]

57. Liao, Q.; Zhang, Y.; Tao, Y.; Ye, J.; Li, C. Economic analysis of an industrial photovoltaic system coupling with battery storage. Int. J. Energy Res. 2019, 43, 6461-6474. [CrossRef]

58. Beltran, H.; Harrison, S.; Egea-Àlvarez, A.; Xu, L. Techno-economic assessment of energy storage technologies for inertia response and frequency support from wind farms. Energies 2020, 13, 3421. [CrossRef]

59. Martinez-Bolanos, J.R.; Udaeta, M.E.M.; Gimenes, A.L.V.; Silva, V.O. da Economic feasibility of battery energy storage systems for replacing peak power plants for commercial consumers under energy time of use tariffs. J. Energy Storage 2020, 29, 101373. [CrossRef]

60. Rallo, H.; Canals Casals, L.; De La Torre, D.; Reinhardt, R.; Marchante, C.; Amante, B. Lithium-ion battery 2nd life used as a stationary energy storage system: Ageing and economic analysis in two real cases. J. Clean. Prod. 2020, 272. [CrossRef]

61. Tsai, C.-T.; Ocampo, E.M.; Beza, T.M.; Kuo, C.-C. Techno-Economic and Sizing Analysis of Battery Energy Storage System for Behind-the-Meter Application. IEEE Access 2020, 8, 203734-203746. [CrossRef]

62. Koutroulis, E.; Kolokotsa, D.; Stravrakakis, G. Optimal design and economic evaluation of a battery energy storage system for the maximization of the energy generated by wind farms in isolated electric grids. Wind Eng. 2009, 33, 55-81. [CrossRef]

63. Papadopoulos, D.P.; Maltas, E.Z. Design, Operation and Economic Analysis of Autonomous Hybrid PV-Diesel Power Systems Including Battery Storage. J. Electr. Eng. 2010, 61, 3-10. [CrossRef]

64. Ren, L.; Tang, Y.; Shi, J.; Dou, J.; Zhou, S.; Jin, T. Techno-economic evaluation of hybrid energy storage technologies for a solar-wind generation system. Phys. C Supercond. Its Appl. 2013, 484, 272-275. [CrossRef]

65. Escalante Soberanis, M.A.; Mithrush, T.; Bassam, A.; Mérida, W. A sensitivity analysis to determine technical and economic feasibility of energy storage systems implementation: A flow battery case study. Renew. Energy 2018, 115, 547-557. [CrossRef]

66. Bai, B.; Xiong, S.; Song, B.; Xiaoming, M. Economic analysis of distributed solar photovoltaics with reused electric vehicle batteries as energy storage systems in China. Renew. Sustain. Energy Rev. 2019, 109, 213-229. [CrossRef]

67. Chagnard, A.; Francois, B. Technical and economic analysis of a regulatory call for PV plants with energy storage in French Islands. Renew. Energy Power Qual. J. 2019, 17, 394-398. [CrossRef]

68. Chiacchio, F.; Famoso, F.; Cedola, L. Grid-Connected Photovoltaic Power Plant with a and the South of Italy. Energies 2019, 12, 2356. [CrossRef]

69. Esparcia, E.A.; Castro, M.T.; Buendia, R.E.; Ocon, J.D. Long-discharge flywheel versus battery energy storage for microgrids: A techno-economic comparison. Chem. Eng. Trans. 2019, 76, 949-954. [CrossRef]

70. Gbadegesin, A.O.; Sun, Y.; Nwulu, N.I. Techno-economic analysis of storage degradation effect on levelised cost of hybrid energy storage systems. Sustain. Energy Technol. Assess. 2019, 36, 100536. [CrossRef]

71. Lata-García, J.; Jurado, F.; Fernández-Ramírez, L.M.; Parra, P.; Larco, V. Techno-economic analysis of several energy storage options for off-grid renewable energy systems. Acta Polytech. Hungarica 2019, 16, 119-141. [CrossRef]

72. Lorenzi, G.; da Silva Vieira, R.; Santos Silva, C.A.; Martin, A. Techno-economic analysis of utility-scale energy storage in island settings. J. Energy Storage 2019, 21, 691-705. [CrossRef]

73. Iliadis, P.; Ntomalis, S.; Atsonios, K.; Nesiadis, A.; Nikolopoulos, N.; Grammelis, P. Energy management and techno-economic assessment of a predictive battery storage system applying a load levelling operational strategy in island systems. Int. J. Energy Res. 2020. [CrossRef] 
74. Kelly, J.J.; Leahy, P.G. Sizing Battery Energy Storage Systems: Using Multi-Objective Optimization to Overcome the Investment Scale Problem of Annual Worth. IEEE Trans. Sustain. Energy 2020, 11, 2305-2314. [CrossRef]

75. Kelly, J.J.; Leahy, P.G. Optimal investment timing and sizing for battery energy storage systems. J. Energy Storage 2020, 28. [CrossRef]

76. Kiptoo, M.K.; Lotfy, M.E.; Adewuyi, O.B.; Conteh, A.; Howlader, A.M.; Senjyu, T. Integrated approach for optimal technoeconomic planning for high renewable energy-based isolated microgrid considering cost of energy storage and demand response strategies. Energy Convers. Manag. 2020, 215, 112917. [CrossRef]

77. Krishnamoorthy, M.; Periyanayagam, A.D.V.R.; Santhan Kumar, C.; Praveen Kumar, B.; Srinivasan, S.; Kathiravan, P. Optimal Sizing, Selection, and Techno-Economic Analysis of Battery Storage for PV/BG-based Hybrid Rural Electrification System. IETE J. Res. 2020, 1-16. [CrossRef]

78. Shabani, M.; Dahlquist, E.; Wallin, F.; Yan, J. Techno-economic comparison of optimal design of renewable-battery storage and renewable micro pumped hydro storage power supply systems: A case study in Sweden. Appl. Energy 2020, 279. [CrossRef]

79. Li, M.-J.; Zhao, W.; Chen, X.; Tao, W.-Q. Economic analysis of a new class of vanadium redox-flow battery for medium- and large-scale energy storage in commercial applications with renewable energy. Appl. Therm. Eng. 2017, 114, 802-814. [CrossRef]

80. Sobieski, D.W.; Bhavaraju, M.P. An economic assessment of battery storage in electric utility systems. IEEE Trans. Power Appar. Syst. 1985, PAS-104, 3453-3459. [CrossRef]

81. Su, W.-F.; Huang, S.-J. Economic analysis for demand-side hybrid photovoltaic and battery energy storage system. IEEE Trans. Ind. Appl. 2001, 37, 171-177. [CrossRef]

82. Rudolf, V.; Papastergiou, K.D. Financial analysis of utility scale photovoltaic plants with battery energy storage. Energy Policy 2013, 63, 139-146. [CrossRef]

83. Han, X.; Ji, T.; Zhao, Z.; Zhang, H. Economic evaluation of batteries planning in energy storage power stations for load shifting. Renew. Energy 2015, 78, 643-647. [CrossRef]

84. Bakke, I.; Fleten, S.-E.; Hagfors, L.I.; Hagspiel, V.; Norheim, B.; Wogrin, S. Investment in electric energy storage under uncertainty: A real options approach. Comput. Manag. Sci. 2016, 13, 483-500. [CrossRef]

85. Maghouli, P.; Soroudi, A.; Keane, A. Robust computational framework for mid-term techno-economical assessment of energy storage. IET Gener. Transm. Distrib. 2016, 10, 822-831. [CrossRef]

86. Quaia, S. Economic evaluation of energy-storage systems for grid-scale applications. Part 1: Methodological approach and selection of candidate technologies. Elektroteh. Vestnik/Electrotech. Rev. 2016, 83, 243-250.

87. Quaia, S. Economic evaluation of energy-storage systems for grid-scale applications. Part 2: Analysis and results. Elektroteh. Vestnik/Electrotech. Rev. 2016, 83, 251-258.

88. Tamura, S. Economic Analysis of Hybrid Battery Energy Storage Systems Applied to Frequency Control in Power System. Electr. Eng. Jpn. (Engl. Transl. Denki Gakkai Ronbunshi) 2016, 195, 24-31. [CrossRef]

89. Thompson, C.C.; Konstantinos Oikonomou, P.E.; Etemadi, A.H.; Sorger, V.J. Optimization of Data Center Battery Storage Investments for Microgrid Cost Savings, Emissions Reduction, and Reliability Enhancement. IEEE Trans. Ind. Appl. 2016, 52, 2053-2060. [CrossRef]

90. Lin, B.; Wu, W. Economic viability of battery energy storage and grid strategy: A special case of China electricity market. Energy 2017, 124, 423-434. [CrossRef]

91. Fleer, J.; Zurmühlen, S.; Meyer, J.; Badeda, J.; Stenzel, P.; Hake, J.-F.; Sauer, D.U. Techno-economic evaluation of battery energy storage systems on the primary control reserve market under consideration of price trends and bidding strategies. J. Energy Storage 2018, 17, 345-356. [CrossRef]

92. Pandžić, K.; Pandžić, H.; Kuzle, I. Coordination of Regulated and Merchant Energy Storage Investments. IEEE Trans. Sustain. Energy 2018, 9, 1244-1254. [CrossRef]

93. Perkins, G. Techno-economic comparison of the levelised cost of electricity generation from solar PV and battery storage with solar PV and combustion of bio-crude using fast pyrolysis of biomass. Energy Convers. Manag. 2018, 171, 1573-1588. [CrossRef]

94. Segundo Sevilla, F.R.; Parra, D.; Wyrsch, N.; Patel, M.K.; Kienzle, F.; Korba, P. Techno-economic analysis of battery storage and curtailment in a distribution grid with high PV penetration. J. Energy Storage 2018, 17, 73-83. [CrossRef]

95. Yianni, C.; Efthymiou, V.; Georghiou, G. Economic viability of battery energy storage for the provision of frequency regulation service. J. Power Technol. 2018, 98, 403.

96. Zurita, A.; Mata-Torres, C.; Valenzuela, C.; Felbol, C.; Cardemil, J.M.; Guzmán, A.M.; Escobar, R.A. Techno-economic evaluation of a hybrid CSP+PV plant integrated with thermal energy storage and a large-scale battery energy storage system for base generation. Sol. Energy 2018, 173, 1262-1277. [CrossRef]

97. Ehsan, A.; Yang, Q. Coordinated Investment Planning of Distributed Multi-Type Stochastic Generation and Battery Storage in Active Distribution Networks. IEEE Trans. Sustain. Energy 2019, 10, 1813-1822. [CrossRef]

98. Engels, J.; Claessens, B.; Deconinck, G. Techno-economic analysis and optimal control of battery storage for frequency control services, applied to the German market. Appl. Energy 2019, 242, 1036-1049. [CrossRef]

99. Kim, H.T.; Jin, Y.G.; Yoon, Y.T. An economic analysis of load leveling with battery energy storage systems (BESS) in an electricity market environment: The Korean case. Energies 2019, 12, 1608. [CrossRef]

100. Bahloul, M.; Khadem, S.K. An analytical approach for techno-economic evaluation of hybrid energy storage system for grid services. J. Energy Storage 2020, 31. [CrossRef] 
101. Jumare, I.A. Energy storage with salt water battery: A preliminary design and economic assessment. J. Energy Storage 2020, 27, 101130. [CrossRef]

102. Mostafa, M.H.; Abdel Aleem, S.H.E.; Ali, S.G.; Ali, Z.M.; Abdelaziz, A.Y. Techno-economic assessment of energy storage systems using annualized life cycle cost of storage (LCCOS) and levelized cost of energy (LCOE) metrics. J. Energy Storage 2020, 29. [CrossRef]

103. Raugei, M.; Peluso, A.; Leccisi, E.; Fthenakis, V. Life-Cycle Carbon Emissions and Energy Return on Investment for $80 \%$ Domestic Renewable Electricity with Battery Storage in California (U.S.A.). Energies 2020, 13, 3934. [CrossRef]

104. Sun, B.; He, X.; Zhang, W.; Li, Y.; Gong, M.; Yang, Y.; Su, X.; Zhu, Z.; Gao, W. Control strategies and economic analysis of an LTO battery energy storage system for AGC ancillary service. Energies 2020, 13, 505. [CrossRef]

105. Rawa, M.; Abusorrah, A.; Al-Turki, Y.; Mekhilef, S.; Mostafa, M.H.; Ali, Z.M.; Aleem, S.H.E.A. Optimal allocation and economic analysis of battery energy storage systems: Self-consumption rate and hosting capacity enhancement for microgrids with high renewable penetration. Sustainability 2020, 12, 10144. [CrossRef]

106. Kirli, D.; Kiprakis, A. Techno-economic potential of battery energy storage systems in frequency response and balancing mechanism actions. J. Eng. 2020, 2020, 774-782. [CrossRef]

107. Pavić, I.; Luburić, Z.; Pandžić, H.; Capuder, T.; Andročec, I. Defining and evaluating use cases for battery energy storage investments: Case study in Croatia. Energies 2019, 12, 376. [CrossRef]

108. Davitian, H.; Leigh, R.W. On the economic assessment and optimization of energy storage systems. Energy 1979, 4, 1099-1105 [CrossRef]

109. Aquila, G.; Souza Rocha, L.C.; de Oliveira Pamplona, E.; de Queiroz, A.R.; Rotela, P., Jr.; Balestrassi, P.P.; Fonseca, M.N. Proposed method for contracting of wind-photovoltaic projects connected to the Brazilian electric system using multiobjective programming. Renew. Sustain. Energy Rev. 2018, 97, 377-389. [CrossRef]

110. Perianes-Rodriguez, A.; Waltman, L.; van Eck, N.J. Constructing bibliometric networks: A comparison between full and fractional counting. J. Informetr. 2016, 10, 1178-1195. [CrossRef]

111. Van Eck, N.J.; Waltman, L. Measuring Scholarly Impact; Ding, Y., Rousseau, R., Wolfram, D., Eds.; Springer International Publishing: Cham, Switzerland, 2014; ISBN 978-3-319-10376-1.

112. Waltman, L.; van Eck, N.J.; Noyons, E.C.M. A unified approach to mapping and clustering of bibliometric networks. J. Informetr. 2010, 4, 629-635. [CrossRef]

113. Kabir, M.N.; Mishra, Y.; Ledwich, G.; Xu, Z.; Bansal, R.C. Improving voltage profile of residential distribution systems using rooftop PVs and Battery Energy Storage systems. Appl. Energy 2014, 134, 290-300. [CrossRef]

114. Ciez, R.E.; Whitacre, J.F. The cost of lithium is unlikely to upend the price of Li-ion storage systems. J. Power Sources 2016, 320, 310-313. [CrossRef]

115. Nykvist, B.; Nilsson, M. Rapidly falling costs of battery packs for electric vehicles. Nat. Clim. Chang. 2015, 5, 329-332. [CrossRef]

116. Boicea, V.A. Energy storage technologies: The past and the present. Proc. IEEE 2014, 102, 1777-1794. [CrossRef]

117. Sabihuddin, S.; Kiprakis, A.E.; Mueller, M. A numerical and graphical review of energy storage technologies. Energies 2015, 8 , 172-216. [CrossRef]

118. Molina, M.G. Energy Storage and Power Electronics Technologies: A Strong Combination to Empower the Transformation to the Smart Grid. Proc. IEEE 2017, 105, 2191-2219. [CrossRef]

119. Argyrou, M.C.; Christodoulides, P.; Kalogirou, S.A. Energy storage for electricity generation and related processes: Technologies appraisal and grid scale applications. Renew. Sustain. Energy Rev. 2018, 94, 804-821. [CrossRef]

120. Enescu, D.; Chicco, G.; Porumb, R.; Seritan, G. Thermal energy storage for grid applications: Current status and emerging trends. Energies 2020, 13, 340. [CrossRef]

121. Hossain, E.; Faruque, H.M.R.; Sunny, M.S.H.; Mohammad, N.; Nawar, N. A comprehensive review on energy storage systems: Types, comparison, current scenario, applications, barriers, and potential solutions, policies, and future prospects. Energies 2020, 13, 3651. [CrossRef]

122. Wali, S.B.; Hannan, M.A.; Reza, M.S.; Ker, P.J.; Begum, R.A.; Rahman, M.S.A.; Mansor, M. Battery storage systems integrated renewable energy sources: A biblio metric analysis towards future directions. J. Energy Storage 2021, 35, 102296. [CrossRef]

123. Zakeri, B.; Syri, S. Electrical energy storage systems: A comparative life cycle cost analysis. Renew. Sustain. Energy Rev. 2015, 42, 569-596. [CrossRef]

124. Rodway, J.; Musilek, P.; Misak, S.; Prokop, L. Prediction of PV power quality: Total harmonic distortion of current. In Proceedings of the 2013 IEEE Electrical Power \& Energy Conference, Halifax, NS, Canada, 21-23 August 2013; IEEE: New York, NY, USA, 2013; pp. 1-4.

125. Akbari, H.; Browne, M.C.; Ortega, A.; Huang, M.J.; Hewitt, N.J.; Norton, B.; McCormack, S.J. Efficient energy storage technologies for photovoltaic systems. Sol. Energy 2019, 192, 144-168. [CrossRef]

126. Schmidt, O.; Hawkes, A.; Gambhir, A.; Staffell, I. The future cost of electrical energy storage based on experience rates. Nat. Energy 2017, 2, 1-8. [CrossRef]

127. Akinyele, D.O.; Rayudu, R.K. Review of energy storage technologies for sustainable power networks. Sustain. Energy Technol. Assess. 2014, 8, 74-91. [CrossRef] 
128. Bullich-Massagué, E.; Cifuentes-García, F.J.; Glenny-Crende, I.; Cheah-Mañé, M.; Aragüés-Peñalba, M.; Díaz-González, F.; Gomis-Bellmunt, O. A review of energy storage technologies for large scale photovoltaic power plants. Appl. Energy 2020, 274, 115213. [CrossRef]

129. Luo, X.; Wang, J.; Dooner, M.; Clarke, J. Overview of current development in electrical energy storage technologies and the application potential in power system operation. Appl. Energy 2015, 137, 511-536. [CrossRef]

130. Shah, S.K.; Hellany, A.; Nagrial, M.; Rizk, J. Power quality improvement factors: An overview. In Proceedings of the 2014 11th Annual High Capacity Optical Networks and Emerging/Enabling Technologies (Photonics for Energy), HONET-PfE 2014, Charlotte, NC, USA, 15-17 December 2014; pp. 138-144. [CrossRef]

131. Mundackal, J.A.; Varghese, A.C.; Sreekala, P.; Reshmi, V. Grid power quality improvement and battery energy storage in wind energy systems. In Proceedings of the 2013 Annual International Conference on Emerging Research Areas and 2013 International Conference on Microelectronics, Communications and Renewable Energy, Kanjirapally, India, 4-6 June 2013. [CrossRef]

132. Lam, K.H.; Lai, T.M.; Lo, W.C.; To, W.M. The application of dynamic modelling techniques to the grid-connected PV (photovoltaic) systems. Energy 2012, 46, 264-274. [CrossRef]

133. Mahela, O.P.; Shaik, A.G. Power quality improvement in distribution network using DSTATCOM with battery energy storage system. Int. J. Electr. Power Energy Syst. 2016, 83, 229-240. [CrossRef]

134. Fonseca, M.N.; de Oliveira Pamplona, E.; de Mello Valerio, V.E.; Aquila, G.; Rocha, L.C.S.; Rotela, P., Jr. Oil price volatility: A real option valuation approach in an African oil field. J. Pet. Sci. Eng. 2017, 150, 297-304. [CrossRef]

135. Rocha, L.C.S.; Aquila, G.; Rotela, P., Jr.; de Paiva, A.P.; de Oliveira Pamplona, E.; Balestrassi, P.P. A stochastic economic viability analysis of residential wind power generation in Brazil. Renew. Sustain. Energy Rev. 2018, 90, 412-419. [CrossRef]

136. Steffen, B. Estimating the cost of capital for renewable energy projects. Energy Econ. 2020, 88, 104783. [CrossRef] 